\title{
Review of the Lower Palaeozoic basin in North Greenland with special emphasis on petroleum geology
}

\author{
F. G. Christiansen
}

The Lower Palaeozoic sediments of North Greenland were deposited in the eastward extension of the Franklinian basin of Ellesmere Island, and are exposed today in a broad $\mathrm{E}-\mathrm{W}$ trending zone across North Greenland about $800 \mathrm{~km}$ long and up to $200 \mathrm{~km}$ wide (figs 4 and 5).

Numerous accounts on the geology of this region have appeared, particularly over the last decade following field work by GGU in 1978-1980 and 1984-1985 (Rapp. Grønlands geol. Unders. 88, 99, 106, 126, 133).
A number of reviews with quite different approaches summarize the geology with respect to the history of exploration (Dawes \& Christie, 1982, Christie \& Dawes, in press), general geology (Dawes, 1971, 1976; Dawes \& Peel, 1981; Higgins, 1986), stratigraphy (Peel, 1982, 1985), deformation (Higgins et al., 1985) and basin development (Surlyk \& Hurst, 1984; Higgins et al., in press). Reviews concerning the geological implications for future petroleum activities have, however,
Fig. 4. Map showing the tectonic position of the Lower Palaeozoic sediments in North Greenland. Dark tone: exposures of the Lower Palaeozoic Franklinian basin in North Greenland, full lines: active spreading zones, thin lines: fracture zones, dash lines: extinct spreading zones (?), lines of crosses: ridge of uncertain origin, line of dots: ridge of continental origin.

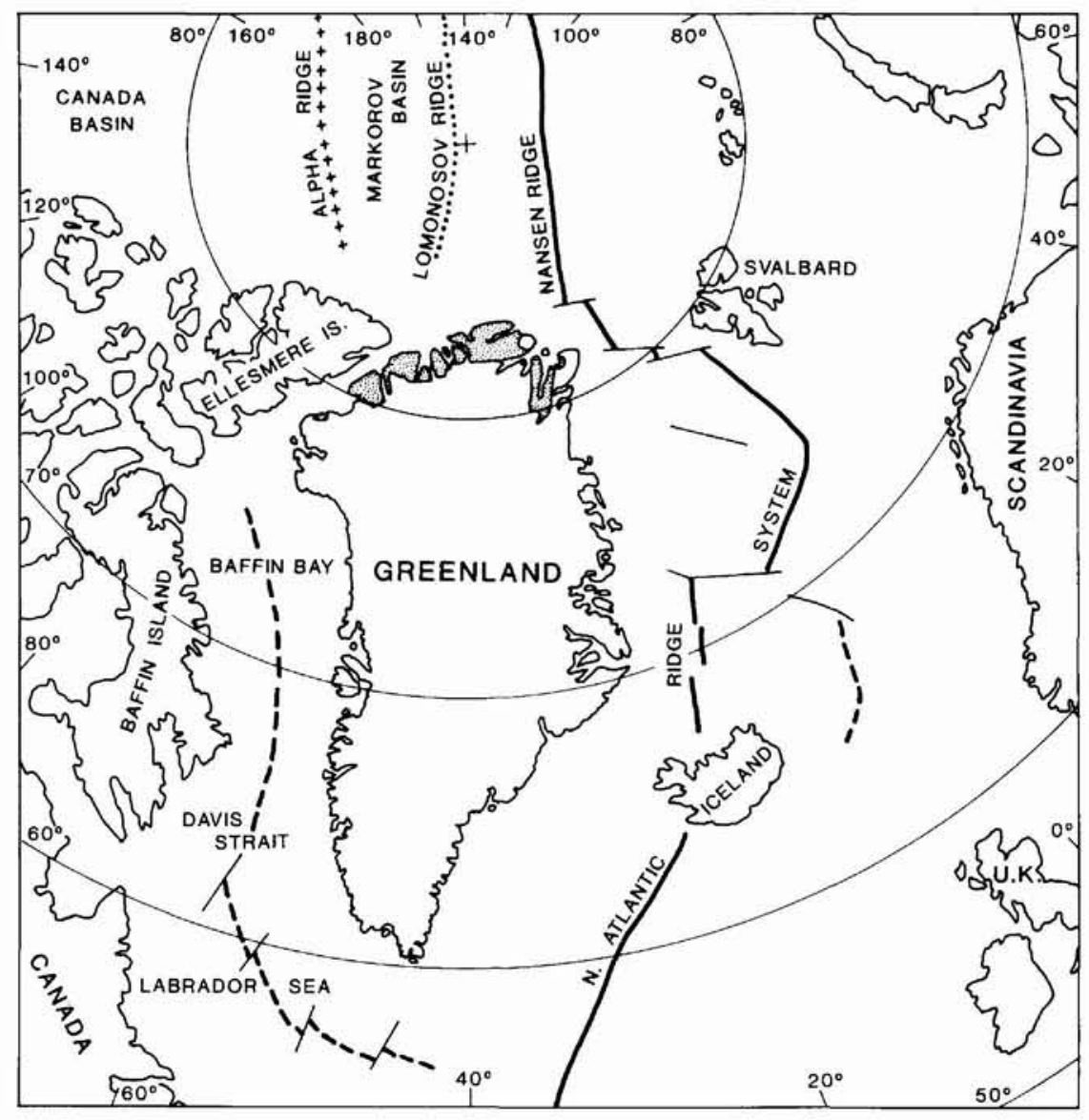




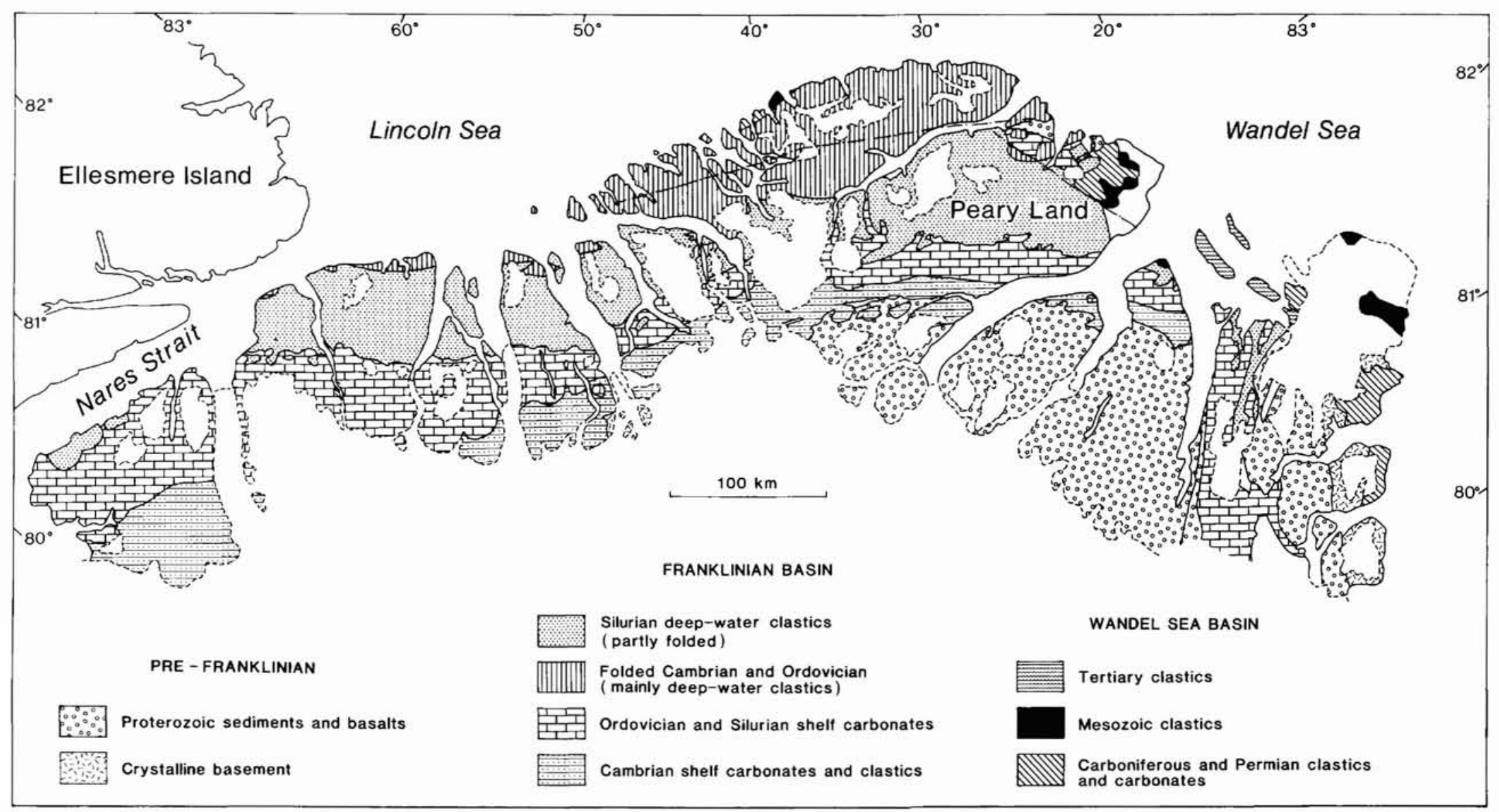

Fig. 5. Geological map of North Greenland. Simplified and modified after Dawes (1976), Higgins et al. (in press), and Christiansen et al. (in press). 
been very limited (Henderson, 1976; Christiansen et al., in press).

\section{Tectonic setting}

The segment of the Franklinian basin represented in North Greenland developed in Early Palaeozoic time and is now exposed along the northern margin of the Greenlandic Precambrian shield. Cratonic rocks (Archaean-Proterozoic crystalline basement and Middle to Late Proterozoic volcanics and sediments) underlie at least the southern part of the basin in North Greenland.

During the time of basin development, from latest Proterozoic or earliest Cambrian to Devonian time, the Greenland craton formed part of the Laurentia continent with a palaeogeographic position of the study area between latitudes $5^{\circ} \mathrm{S}$ and $15^{\circ} \mathrm{N}$ (Scotese et al., 1979). On the basis of the east-west sediment transport direction, parallel to the continental margin, Surlyk \& Hurst (1983) proposed that the basin took the form of a relatively narrow trough with a northern barrier. Two main hypotheses were proposed: the presence of a narrow ocean with the spreading axis ridge forming the barrier or an aulacogen model with rifting from the Iapetus Ocean extending deeply into the continent. Earlier, a back-arc model had been proposed with the Pearya Geanticline in northern Ellesmere Island and its intrusions and volcanic rocks forming in this setting (Frisch, 1974; Christie, 1979; Trettin \& Balkwill, 1979; Trettin, 1987). However, there is no evidence in the Greenland part of the basin in support of this model.

The final closure of the Iapetus Ocean in the Late Silurian and the subsequent continental collision formed the East Greenland Caledonian fold belt. This episode also strongly affected the Greenland part of the Franklinian basin; most of the Silurian turbidites were derived from the rising Caledonide mountains (Surlyk, 1982; Hurst et al., 1983), and the subsidence history was affected by loading and local uplift (causing for instance the unconformity below the Wandel Valley Formation) (Surlyk \& Hurst, 1984).

The Ellesmerian orogeny brought deposition in the Franklinian basin to a close in Late Devonian to Early Carboniferous time (fig. 6) and gave rise to the North Greenland fold belt. The fold belt trends approximately east-west, as do the metamorphic zones, roughly parallel to the margin of the deep-water trough (Dawes \& Soper, 1973; Dawes, 1976; Higgins et al., 1985); this implies collision with a northern continental mass of either cratonic or arc affinity, probably the Siberian block.

Plate tectonic reconstructions are important in petroleum exploration because by extrapolation they shed

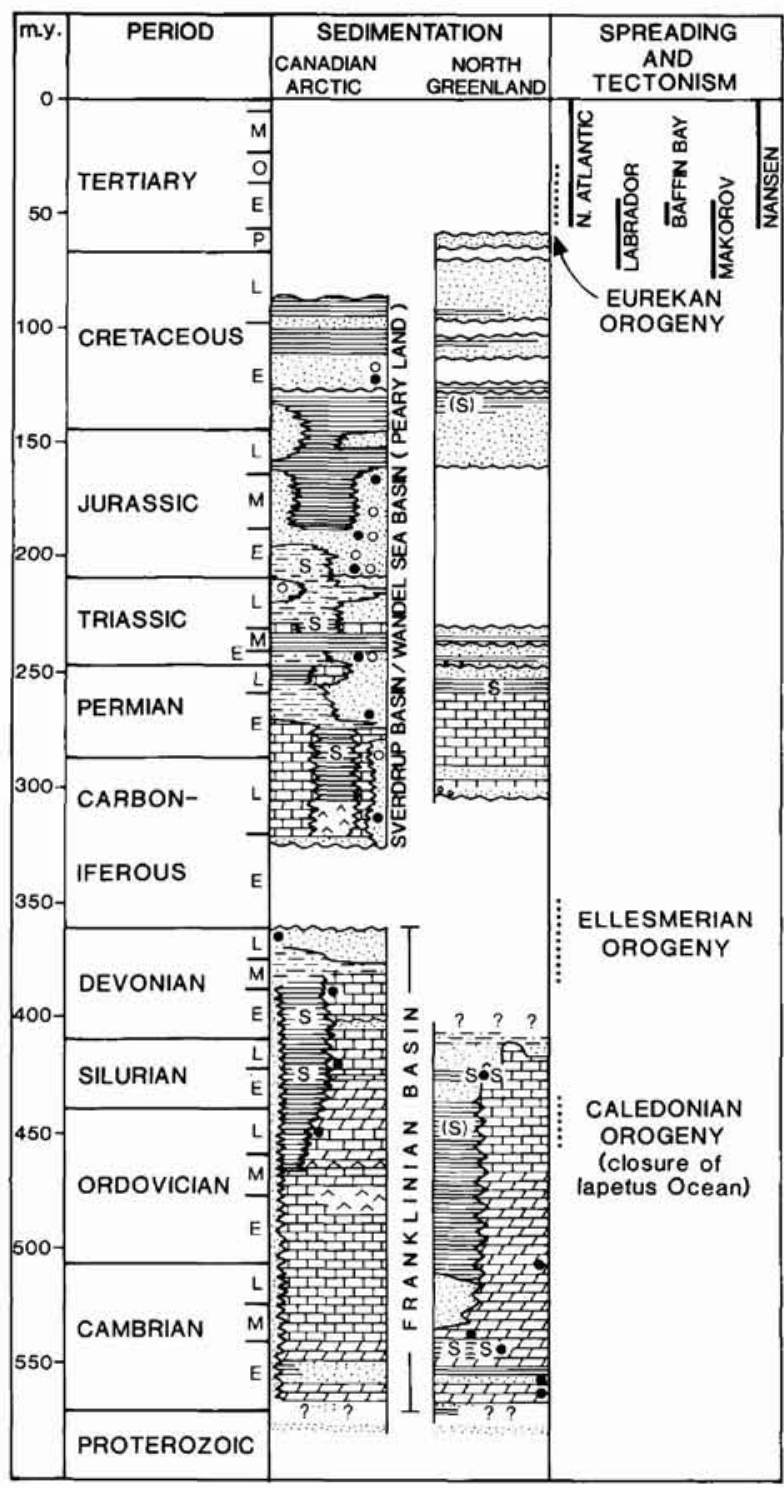

Fig. 6. Simplified diagram showing the relations between stratigraphy, sedimentation, source rock deposition(s), hydrocarbon occurrences (filled circles: oil and bitumen, open circles: gas), ocean spreading and tectonism in North Greenland and Canadian Arctic. Based on numerous sources mentioned in text, in particular Dawes \& Kerr (1982 and papers herein), Kerr (1980), Rayer (1981).

light on the development of the least known parts of the tectonic and sedimentary history. Often this approach is applied to predict potential source and reservoir facies and prospect types. Various basin classifications have been proposed over the past 20 years (e.g. Klemme, 1971; Bally \& Snelson, 1980; Stoneley, 1981; Bois et al., 1982; St. John et al., 1984; Kingston et al., 1985). These 
classification systems are generally difficult to apply to North Greenland, particularly due to lack of data in respect to the northern border of the basin and the limited knowledge of the Late Palaeozoic and Mesozoic histories. It should, however, be noted that the Franklinian basin differs from many oil-producing Lower Palaeozoic basins; the latter are mainly of an intra-cratonic type with very long and slow subsidence histories (e.g. the Michigan basin and several basins in Australia, South America and northern Africa). An oil-producing basin with a strong resemblance to North Greenland in age and tectonic setting occurs in Alberta, Canada. Many other Lower Palaeozoic basins with similarities to North Greenland only have a very low petroleum potential, mainly because of very deep subsidence and later orogenesis caused by continental collision (e.g. the Lower Palaeozoic successions in the Caledonides in Europe and North America).

\section{Basin evolution and source rock deposition}

The tectonic/sedimentological evolution of the Lower Palaeozoic deep-water basin in North Greenland was described in terms of 9 development stages by Surlyk \& Hurst $(1983,1984)$, an approach recently expanded to incorporate the shelf areas by Higgins $e t$ al. (in press).

Throughout the depositional period, the region was characterized by major generally east-west trending facies belts (fig. 5). In the southern shelf areas mainly carbonate shallow-water deposition took place, bordered to the north by outer shelf and slope mudstones (fig. 6). In the north mainly siliciclastic deep-water sedimentation prevailed in the trough. With time, the facies boundaries moved southwards during a stepwise basin expansion. The major facies boundaries were probably controlled by deep crustal faults, some of which have no surface expressions today, while others were reactivated during Ellesmerian deformation (see e.g. Soper \& Higgins, 1987). Of particular importance to the present study is the Navarana Fjord escarpment (Hurst \& Surlyk, 1983; Surlyk \& Hurst, 1984; Escher \& Larsen, 1987; Surlyk \& Ineson, 1987a,b) which separated carbonate and turbidite deposition in Late Ordovician to Early Silurian time. The Permin Land flexure (Surlyk \& Hurst, 1983, 1984), largely corresponding to the Early Silurian hinge line of Sønderholm et al. (1987), also has important implications for the petroleum geology. This lineament or flexure seems to have developed as a response to loading from the thick and rapidly deposited Lower Silurian turbidites. It is considered as a flexure line with increasing subsidence to the north and is not necessarily controlled in position by deeper crustal structures. The flexure controls the position of the Early to Late Silurian reef-belt, which developed as a series of large slope mounds along the northern margin of the platform (Sønderholm \& Harland, 1989a).

Towards the south, shelf sedimentation was dominated by carbonates, with the exception of a single period of siliciclastic sedimentation in earliest Cambrian time. In the Early Cambrian, carbonate deposition extended to a position just north of the present northern coast of Nyeboe Land; in Late Ordovician to Early Silurian, the Navarana Fjord escarpment defined the boundary between the carbonate platform and the deep-water trough. Later during the Early Silurian (late Llandovery) the platform margin moved to a more southerly position controlled by the Permin Land flexure. The southern limit of carbonate deposition is not known due to cover by the Inland Ice but the platform was probably at least $200 \mathrm{~km}$ wide and may have been considerably wider as in the Canadian Arctic Interior Platform (fig. 3). The thickness of the shelf deposits suggests a slightly decreasing subsidence rate from the Early Cambrian to the earliest Silurian with a relatively uniform history along depositional strike and a much higher subsidence rate in the Early to Late Silurian (M. Sønderholm, personal communication, 1988). However, the eastern part of the shelf sequence in Peary Land was uplifted and partially eroded in the earliest Ordovician, corresponding to the strata underlying the unconformity at the base of the Wandel Valley Formation, probably in response to Caledonian tectonism to the east (Hurst \& Surlyk, 1983; Surlyk \& Hurst, 1984).

Trough sedimentation was dominated by turbiditic sandstones with minor siltstones and conglomerates. The Ordovician succession is relatively thin compared to the Cambrian and Silurian part reflecting considerable variation in subsidence rate. The trough may be traced for more than $800 \mathrm{~km}$ along strike in North Greenland and continues into Ellesmere Island. The width is not known but was probably between 100 and $200 \mathrm{~km}$ throughout much of the depositional period with the exception of the Early Silurian to Late Silurian (earliest Devonian?) when the deep-water basin expanded strongly towards the south.

The outer shelf and slope deposits, which are particularly interesting in the present study due to their source potential, comprise a mixture of mainly black shales, lime mudstones and conglomerates. The configuration of the outer shelf and slope varied considerably with time and therefore has strong implications for the source potential. In earliest Cambrian time this zone was very wide but apparently without source rock deposition due to well oxygenated conditions. In the Early to Middle Cambrian, outer shelf deposition took place in a 
wide belt under mainly anoxic conditions, and good source rocks formed. This pattern changed from the Middle Cambrian throughout most of the Ordovician when outer shelf-slope sedimentation occurred in a narrower zone. During Late Ordovician to Early Silurian time the Navarana Fjord escarpment defined a narrow by-pass margin between shallow-water carbonate deposition and deep-water siliciclastic sedimentation, and the formation of organic-rich units was very restricted. A wide outer shelf prevailed in mid-Silurian time when black shales overlapped the shallow-water carbonates. This was a period of major source rock deposition.
Stratigraphy, reservoir and source rock studies

The lithostratigraphic nomenclature applied in the present study to the Lower Palaeozoic shelf sequence and slope and trough sequence is shown in figs 7 and 8 . Information on the different units is summarized below, either at formation or group level and includes data on: main lithology, distribution and thickness, reference to general descriptions and to information of reservoir and source rock quality.

\section{SHELF SEQUENCE}

\section{GROUP FORMATION}

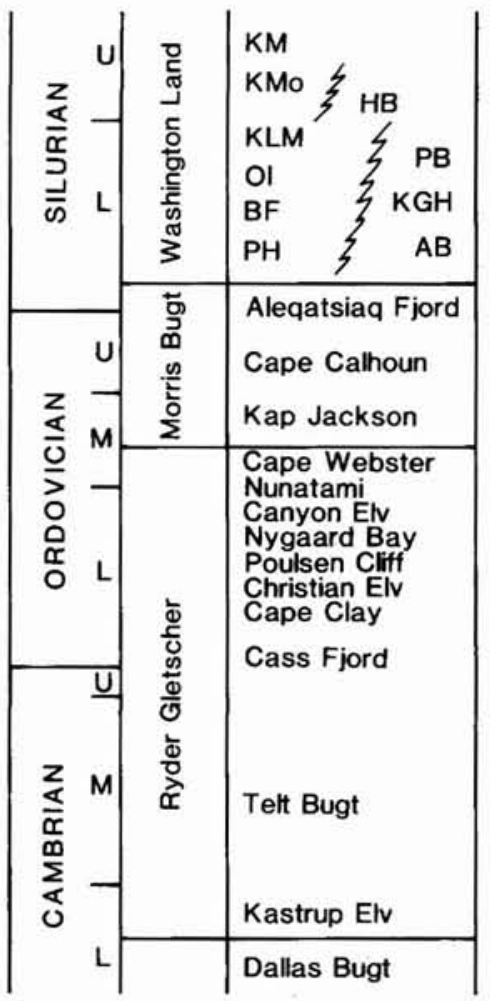

WASHINGTON LAND
GROUP FORMATION

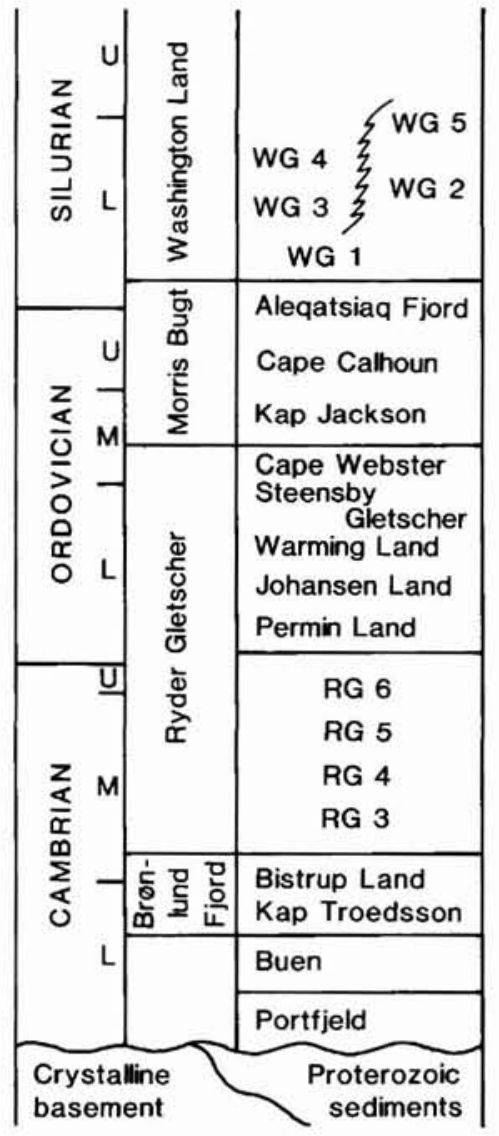

HALL LAND - NARES LAND
GROUP FORMATION

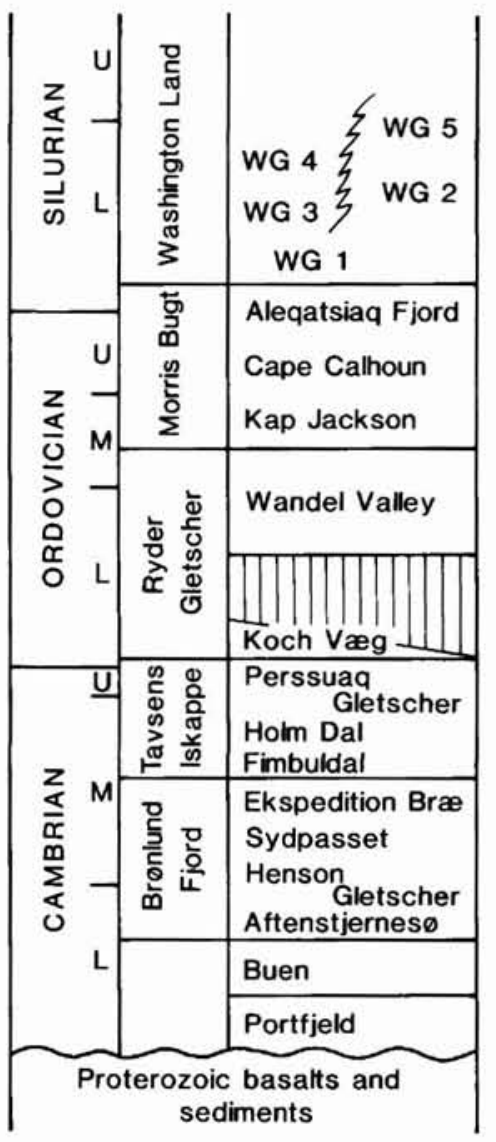

FREUCHEN LAND -

W. PEARY LAND

Fig. 7. Stratigraphic nomenclature of the shelf sequence in central and western North Greenland. Modified after Henriksen (1987) and Higgins et al. (in press). AB: Adams Bjerg, BF; Bessels Fjord, HB: Hauge Bjerg, KGH: Kap Godfred Hansen, KLM: Kap Lucie Marie, KM: Kap Maynard, KMo: Kap Morton, OI: Offley Island, PB: Pentamerus Bjerge, PH: Petermann Halvø, RG: Ryder Gletscher Group; WG: Washington Land Group. 


\section{Crystalline basement}

Lithology: gneisses with minor amphibolite and supracrustals.

Distribution: only exposed at the head of Victoria Fjord and in Inglefield Land.

References: Henriksen \& Jepsen (1985), Hansen et al. (1987).

Reservoir rocks: not likely.

\section{Proterozoic sediments}

Lithology: sandstones and volcanics.

Distribution: Inglefield Land and Peary Land, probably thin in central North Greenland.

Thickness: $25 \mathrm{~m}$ in Wulff Land to more than $2 \mathrm{~km}$ in Peary Land.

References: Jepsen (1971), Christie \& Ineson (1979), Clemmensen (1979), Collinson (1979, 1980), Dawes et al. (1982), Peel et al. (1982).

Reservoir rocks: possible?, most sandstones are altered by dykes and volcanics.

Source rocks: not likely.

\section{Lower Palaeozoic shelf sequence}

\section{Lower Cambrian shelf siliciclastics and carbonates}

Lithostratigraphy: Skagen Group.

Lithology: siltstones and sandstones in lower part, dolomites in upper part.

Distribution: known in northern Wulff Land and easternmost Peary Land.

Thickness: $500-600 \mathrm{~m}$ in northern Wulff Land.

References: Christie \& Ineson (1979), Friderichsen et al. (1982), Higgins \& Soper (1985), Surlyk \& Ineson (1987a).

Reservoir rocks: oolitic and pisolitic grainstones possible.

Source rocks: none, shales contain less than $1 \%$ TOC (Christiansen et al., 1985).

\section{Lower Cambrian shelf carbonates}

Lithostratigraphy: Portfjeld Formation.

Lithology: dolomites.

Distribution: throughout North Greenland.

Thickness: $200-800 \mathrm{~m}$, generally increasing northwards towards the shelf edge.

References: Jepsen (1971), Christie \& Ineson (1979), O'Connor (1979), Surlyk \& Ineson (1987a), Higgins et al. (in press).
Reservoir rocks: ?, asphalt seepage in Wulff Land, bitumen in upper part of the formation in Freuchen Land and Peary Land.

Source rocks: none, very low TOC contents with the exception of a $10-15 \mathrm{~m}$ thick interval of dark cherty dolomite near the base of the formation in Peary Land (O'Connor, 1979; Rolle \& Wrang, 1981).

\section{Lower Cambrian shelf siliciclastics}

Lithostratigraphy: Buen and Dallas Bugt Formations.

Lithology: mainly sandstones in the lower part, mainly shales in the upper part.

Distribution: throughout North Greenland.

Thickness: $250-500 \mathrm{~m}$, generally decreasing towards the north.

References: Jepsen (1971), Christie \& Ineson (1979), Hurst \& Peel (1979), Peel \& Christie (1982), Davis \& Higgins (1987), Higgins et al. (in press).

Reservoir rocks: poor to good, porosities in strongly cemented sandstones are up to $10 \%$ (see Chapter 7), hydrocarbon staining common in the southern part of Wulff Land.

Source rocks: none, very low content of TOC in shales, all 21 recorded values are below $0.2 \%$ (Rolle \& Wrang, 1981; Christiansen et al., 1985).

\section{Lower Cambrian - Middle Ordovician shelf carbonates}

Lithostratigraphy: Brønlund Fjord, Tavsens Iskappe and Ryder Gletscher Groups.

Lithology: dolomites, limestones with some shales and sandstones (Brønlund Fjord and Tavsens Iskappe Groups), dolomites with minor sandstones (Ryder Gletscher Group).

Distribution: throughout North Greenland.

Thickness: $900-1500 \mathrm{~m}$, decreasing towards the north and east.

References: Henriksen \& Peel (1976), Christie \& Peel (1977), Ineson \& Peel (1980, 1987, in press), Ineson (1985), Peel \& Wright (1985), Sønderholm \& Due (1985), Christiansen et al. (1987), Higgins et al. (in press).

Reservoir rocks: several possibilities, sandstones in Henson Gletscher and Sæterdal Formations of the Brønlund Fjord Group, vuggy carbonates in the Aftenstjernes $\emptyset$ and Henson Gletscher Formations of the Brønlund Fjord Group. Macroscopic bitumen and hydrocarbon staining are common in these units (see Chapter 7). 
Source rocks: The Henson Gletscher Formation contains good to excellent source rocks and has consequently been one of the main targets of the present study (Christiansen \& Rolle, 1985; Christiansen et al., 1985, 1986, 1987; see further details in later chapters).

\section{Middle Ordovician to Lower Silurian shelf carbonates}

Lithostratigraphy: Morris Bugt Group.

Lithology: limestones.

Distribution: throughout North Greenland.

Thickness: $620-760 \mathrm{~m}$.

\section{SLOPE AND TROUGH SEQUENCE}

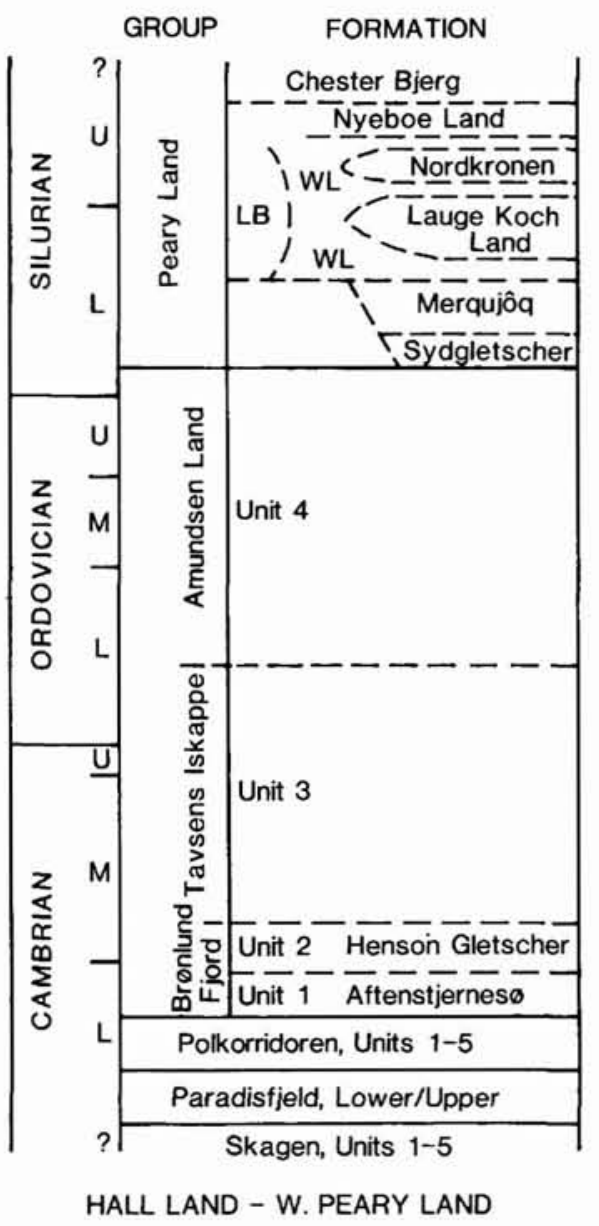

Fig. 8. Stratigraphic nomenclature of the slope and trough sequence in central and western North Greenland. Modified after Henriksen (1987) and Higgins et al. (in press). LB: Lafayette Bugt, WL: Wulff Land.
References: Peel \& Hurst (1980), Sønderholm et al. (1987), Higgins et al. (in press), Smith et al. (1989), Sønderholm \& Harland (1989a,b).

Reservoir rocks: ?, some bitumen in Aleqatsiaq Fjord Formation.

Source rocks: none, a few intervals in Aleqatsiaq Fjord Formation contain more than $1 \%$ TOC (Christiansen et al., 1985).

\section{Silurian shelf carbonates}

Lithostratigraphy: Washington Land Group.

Lithology: limestones and dolomites, both as platform and reef facies.

Distribution: throughout North Greenland.

Thickness: $200-1500 \mathrm{~m}$.

References: Hurst (1980a,b, 1981, 1984), Sønderholm et al. (1987), Sønderholm \& Harland (1989a,b).

Reservoir rocks: likely, especially some of the reef complexes which are juxtaposed with shales of source rock and seal quality. Bitumen is common in debris from the reefs.

Source rocks: none, some of the back and inter-reef lime mudstones contain $1-2 \%$ TOC but display a poor hydrocarbon potential (Christiansen \& NøhrHansen, 1989).

\section{Lower Palaeozoic slope and trough sequence}

\section{Lower Cambrian deep-water carbonates}

Lithostratigraphy: Paradisfjeld Group.

Lithology: carbonate mudstones and conglomerates.

Distribution: widely exposed in north Peary Land and Nansen Land.

Thickness: at least $1 \mathrm{~km}$.

References: Dawes \& Soper (1973), Friderichsen et al. (1982), Friderichsen \& Bengaard (1985).

Reservoir rocks: none, possible reservoirs only occur in postmature areas.

Source rocks: not likely.

\section{Lower Cambrian deep-water siliciclastics}

Lithostratigraphy: Polkorridoren Group.

Lithology: sandstones and shales.

Distribution: widely exposed in north Peary Land and Nansen Land.

Thickness: at least $2 \mathrm{~km}$.

References: Dawes \& Soper (1973), Friderichsen $e t$ al. (1982), Higgins et al. (1985). 
Reservoir rocks: none, possible reservoirs only occur in postmature areas.

Source rocks: not likely.

\section{Middle Cambrian to Lower Silurian slope and trough sediments}

Lithostratigraphy: Vølvedal and Amundsen Land Groups (Brønlund Fjord and Tavsens Iskappe Groups).

Lithology: sandstones, shales, chert, carbonate mudstones and conglomerates.

Distribution: throughout North Greenland from Nyeboe Land to Amundsen Land.

Thickness: $60-450 \mathrm{~m}$ in the area studied (mainly slope facies), about $1 \mathrm{~km}$ in Amundsen Land (trough facies).

References: Friderichsen et al. (1982), Surlyk \& Hurst (1984), Higgins \& Soper (1985), Davis \& Higgins (1987), Ineson \& Peel (in press), Higgins et al. (in press).

Source rocks: The recognition of the correlation between the Henson Gletscher Formation and unit 2 of Higgins \& Soper (1985) considerably increases the known source potential of the Cambrian succession. In addition the black shales of unit 4 of Soper \& Higgins (Amundsen Land Group) are organic-rich. Analyses from Nyeboe Land and Freu- chen Land show several TOC values in excess of $5 \%$, despite the high thermal maturity (Christiansen et al., 1985; U. H. Jacobsen, personal communication 1988).

\section{Silurian sandstone turbidites and shales}

Lithostratigraphy: Peary Land Group.

Lithology: sandstones, shales and conglomerates.

Distribution: throughout North Greenland.

Thickness: from less than $1 \mathrm{~km}$ in the southernmost exposures to more than $5 \mathrm{~km}$ in the northernmost areas.

References: Hurst (1980a), Hurst \& Surlyk (1982), Surlyk \& Hurst (1984), Larsen \& Escher (1985, 1987), Surlyk \& Ineson (1987a,b).

Reservoir rocks: ?, the sandstone turbidites of the Merqujôq, Lauge Koch Land and Nyeboe Land Formations are fine-grained and the porosity/permeability values are low.

Source rocks: The Silurian shales contain good to excellent source rocks and have been considered in detail in the present study (Christiansen et al., \$985, 1986; Christiansen \& Nøhr-Hansen, 1989; see further details in later chapters). The lower part of the Lafayette Bugt and Wulff Land Formations (Thors Fjord Member) are particularly rich in organic matter. 


\section{References}

Aldridge, R. J., Dorning, K. J., Hill, P. J., Richardson, J. B. \& Siveter, D. J. 1979: Microfossil distribution in the Silurian of Britain and Ireland. In Harris, A. L., Holland, C. H. \& Leake, B. E. (edit.) The Caledonides of the British Isles reviewed. Spec. Publ. geol. Soc. Lond. 8, 433-438.

Allaart, J. H. 1965: The Lower Paleozoic sediments of Hall Land, North Greenland. Unpubl. intern. GGU rep., 11 pp.

Allman, M. \& Lawrence, D. F. 1972: Geological laboratory techniques, 335 pp. London: Blandford Press.

Armstrong, H. A. \& Dorning, K. J. 1984: Silurian palynomorphs from the Chester Bjerg Formation, Hall Land, western North Greenland. Rapp. Grønlands geol. Unders. 121, 97-103.

Bally, A. W. \& Snelson, S. 1980: Reals of subsidence. Bull. Can. Petrol. Geol. 28, 9-75.

Batten, D. J. 1981: Palynofacies, organic maturation and source potential for petroleum. In Brooks, J. (edit.) Organic maturation studies and fossil fuel exploration, 201-223. London: Academic Press.

Batten, D. J. 1982: Palynology of shales associated with the Kap Washington Group volcanics, central North Greenland. Rapp. Gronland geol. Unders. 108, 15-23.

Batten, D. J. 1984: Identification of amorphous sedimentary organic matter by transmitted light microscopy. In Brooks, J. (edit.) Petroleum geochemistry and exploration of Europe. Spec. Publ. geol. Soc. Lond. 12, 275-287.

Batten, D. J., Brown, P. E., Dawes, P. R., Higgins, A. K., Koch, B. E., Parson, I. \& Soper, N. J. 1981: Peralkaline volcanicity on the Eurasia basin margin. Nature 294, 150152.

Berry, W. B. N. \& Wilde, P. 1978: Progressive ventilation of the oceans - an explanation for the distribution of the Lower Palcozoic black shales. Am. J. Sci. 278, 257-275.

Bertrand, R. \& Héroux, Y. 1987: Chitinozoan, graptolite, and scolecodont reflectance as an alternative to vitrinite and pyrobitumen reflectance in Ordovician and Silurian strata, Anticosti Island, Quebec, Canada. Bull. Am. Ass. Petrol. Geol. 71, 951-957.

Bishop, R. S., Gehman, H. M. Jr., Young, A. 1983: Concepts for estimating hydrocarbon accumulation and dispersion. Bull. Am. Ass. Petrol. Geol. 67, 337-348.

Bjerreskov, M. 1986: Silurian graptolites from N Greenland. In Hughes, C. P. \& Rickards, R. B. (edit.) Palaeoecology and biostratigraphy of graptolites. Spec. Publ. geol. Soc. Lond. 20, 181-189.

Bois, C., Bouche, P. \& Pelet, R. 1982: Global geologic history and distribution of hydrocarbon reserves. Bull. Am. Ass. Petrol. 66, 1248-1270.

Bryant, I. D. \& Smith, M. P. 1985: Lowermost Ordovician sandstones in central North Greenland. Rapp. Grønlands geol. Unders. 126, 25-30.

Buchardt, B. \& Cederberg, T. 1987: EFP-83 projekt: Stabil isotop geokemi i moderbjergarter, olie og gas i Danmark, afsluttende rapport. Geologisk Centralinstitut, København, $33 \mathrm{pp}$.
Buchardt, B., Clausen, J. \& Thomsen, E. 1986: Carbon isotope composition of Lower Palaeozoic kerogen: Effects of maturation. In Leythaeuser, D. \& Rullkötter, J. (edit.) Advances in organic geochemistry 1985. Org. Geochem. 10, 127-134.

Burgess, J. D. 1974: Microscopic examination of kerogen (dispersed organic matter) in petroleum exploration. Spec. Pap. geol. Soc. Am. 153, 19-30.

Bustin, R. M., Barnes, M. A. \& Barnes, W. C. 1985a: Diagenesis 10. Quantification and modelling of organic diagenesis. Geoscience Canada 12, 4-21.

Bustin, R. M., Cameron, A. R., Grieve, D. A. \& Kalkreuth, W. D. 1985b: Coal petrology, its principles, methods, and applications. Geol. Ass. Can. Short Course Notes 3, 230 pp.

Christiansen, F. G. (edit.) 1988: Petroleum geology of North Greenland. Final report - 'Nordolie'. Unpubl. intern. GGU rep., Part I (text) 231 pp., part II (figures) 101 pp., Appendix I (previously completed papers $43+95$ pp., Appendix II (key data) $87 \mathrm{pp}$.

Christiansen, F. G. \& Nøhr-Hansen, H. 1989: The Silurian shales of central and western North Greenland: evaluation of hydrocarbon source rock potential. Rapp. Grønlands geol. Unders. 143.

Christiansen, F. G. \& Rolle, F. 1985: Project 'Nordolie': hydrocarbon source rock investigations in central North Greenland. Rapp. Grønlands geol. Unders. 125, 17-21.

Christiansen, F. G., Nøhr-Hansen, H., Rolle, F. \& Wrang, P. 1985: Preliminary analysis of the hydrocarbon source rock potential of central and western North Greenland. Rapp. Grønlands geol. Unders. 126, 117-128.

Christiansen, F. G., Nykjær, O. \& Nøhr-Hansen, H. 1986: Source rock investigations and shallow core drilling in central and western North Greenland - project 'Nordolie'. Rapp. Grønlands geol. Unders. 130, 17-23.

Christiansen, F. G., Nøhr-Hansen, H. \& Nykjær, O. 1987: The Cambrian Henson Gletscher Formation: a mature to postmature hydrocarbon source rock sequence from North Greenland. Rapp. Grønlands geol. Unders. 133, 141-157.

Christiansen, F. G., Piasecki, S. \& Stemmerik, L. in press: Petroleum, North Greenland. In Trettin, H. P. (edit.) The Innuitian Orogen and Arctic platform: Canada and Greenland. The geology of North America E. Ottawa: Geological Survey of Canada.

Christic, R. L. 1979: The Franklinian geosyncline in the Canadian Arctic and its relationship to Svalbard. Norsk Polarinstitutt, Skrifter 167, 263-314.

Christie, R. L. \& Dawes, P. R. in press: A history of exploration and geology in the Innuitian region. In Trettin, H. P. (edit.) The Innuitian Orogen and Arctic platform: Canada and Greenland. The geology of North America E. Ottawa: Geological Survey of Canada.

Christie, R. L. \& Ineson, J. R. 1979: Precambrian-Silurian geology of the G. B. Schley Fjord region, eastern Peary Land, North Greenland. Rapp. Grønlands geol. Unders. 88, 63-71. 
Christie, R. L. \& Peel, J. S. 1977: Cambrian-Silurian stratigraphy of Børglum Elv, Peary Land, eastern North Greenland. Rapp. Grønlands geol. Unders. 82, 48 pp.

Clayton, J. L. \& Swetland, P. J. 1978: Subaerial weathering of sedimentary organic matter. Geochim. cosmochim. Acta 42, 305-312.

Clementz, D. M. 1979: Effect of oil and bitumen saturation on source rock pyrolysis. Bull. Am. Ass. Petrol. Geol. 63, 22272232.

Clemmensen, L. B. 1979: Notes on the palaeogeographical setting of the Eocambrian tillite-bearing sequence of southern Peary Land, North Greenland. Rapp. Grønlands geol. Unders. 88, 15-22.

Collinson, J. D. 1979: The Proterozoic sandstones between Heilprin Land and Mylius-Erichsen Land, eastern North Greenland. Rapp. Grønlands geol. Unders. 88, 5-10.

Collinson, J. D. 1980: Stratigraphy of the Independence Fjord Group (Proterozoic) of eastern North Greenland. Rapp. Grønlands geol. Unders. 99, 7-23.

Combaz, A. 1964: Les palynofacies. Rev. Micropaleontol. Paris 7, 205-218.

Curiale, J. A. 1986: Origin of solid bitumens, with emphasis on biological marker results. In Leythaeuser, D. \& Rullkötter, J. (edit.) Advances in organic geochemistry 1985. Org. Geochem. 10, 559-580.

Davies, W. E. 1972: Landscape of northern Greenland. Spec. Rep. Cold Reg. Res. Engng. Lab. 164, 67 pp.

Davis, N. C. \& Higgins, A. K. 1987: Cambrian - Lower Silurian stratigraphy in the fold and thrust zone between northern Nyeboe Land and J. P. Koch Fjord, North Greenland. Rapp. Grønlands geol. Unders. 133, 91-98.

Dawes, P. R. 1971: The North Greenland fold belt and environs. Bull. geol. Soc. Denmark 20, 197-239.

Dawes, P. R. 1976: Precambrian to Tertiary of northern Greenland. In Escher, A. \& Watt, W. S. (edit.) Geology of Greenland, 248-303. Copenhagen: Geol. Surv. Greenland.

Dawes, P. R. 1982: The Nyeboe Land fault zone: a major dislocation on the Greenland coast along northern Nares Strait. In Dawes, P. R. \& Kerr, J. W. (edit.) Nares Strait and the drift of Greenland: a conflict in plate tectonics. Meddr Grønland Geosci. 8, 177-192.

Dawes, P. R. 1984a: Operation Grant Land 1965-1966; a geological exploration programme in Ellesmere Island and North Greenland. Rapp. Grønlands geol. Unders. 121, 5-17.

Dawes, P. R. 1984b: Programme NordGrøn (PNG) 1983-1985: regional mapping and geological studies in western and central North Greenland. Rapp. Grønlands geol. Unders. 120 , 18-24.

Dawes, P. R. \& Christie, R. L. 1982: History of exploration and geology in the Nares Strait region. In Dawes, P. R. \& Kerr, J. W. (edit.) Nares Strait and the drift of Greenland: a conflict in plate tectonics. Meddr Grønland Geosci. 8, 19-36.

Dawes, P. R. \& Christie, R. L. in press: Geomorphic regions of the Innuitian region. In Trettin, H. P. (edit.) The Innuitian Orogen and Arctic platform: Canada and Greenland. The geology of North America E. Ottawa: Geological Survey of Canada.
Dawes, P. R. \& Haller, J. 1979: Historical aspects in the geological investigation of northern Greenland. Part 1: New maps and photographs from the 2nd Thule Expedition 1916-18 and the Bicentenary Jubilee Expedition 1920-1923. Meddr Grønland 200(4), 38 pp.

Dawes, P. R. \& Kerr, J. W. (edit.) 1982: Nares Strait and the drift of Greenland: a conflict in plate tectonics. Meddr Grønland Geosci. 8, 392 pp.

Dawes, P. R. \& Peel, J. S. 1981: The northern margin of Greenland from Baffin Bay to the Greenland Sea. In Nairn, A. E. M., Churkin, M. \& Stehli, F. G. (edit.) The ocean basins and margins 5, 201-264. New York: Plenum Publ. Corp.

Dawes, P. R. \& Soper, N. J. 1970: Geological investigations in northern Peary Land. Rapp. Grønlands geol. Unders. 28, 9-15.

Dawes, P. R. \& Soper, N. J. 1973: Pre-Quaternary history of North Greenland. In Pitcher, M. G. (edit.) Arctic geology. Mem. Am. Ass. Petrol. Geol. 19, 117-134.

Dawes, P. R. \& Soper, N. J. 1979: Structural and stratigraphic framework of the North Greenland fold belt in Johannes V. Jensen Land, Peary Land. Rapp. Grønlands geol. Unders. 93, $40 \mathrm{pp}$.

Dawes, P. R. \& Soper, N. J. 1973: Pre-Quaternary history of North Greenland. In Pitcher, M. G. (edit.) Arctic geology. Mem. Am. Ass. Petrol. Geol. 19, 117-134.

W. (edit.) Nares Strait and the drift of Greenland: a conflict in plate tectonics. Meddr Grønland Geosci. 8, 89-104.

Deines, P. 1980: The isotopic composition of reduced organic matter. In Fritz, P. \& Fontez, J. Ch. (edit.) Handbook of environmental isotope geochemistry. Vol. 1, The terrestrial environment, 329-407. Amsterdam: Elsevier.

Demaison, G. 1984: The generative basin concept. In Demaison, G. \& Murris, R. J. (edit.) Petroleum geochemistry and basin evaluation. Mem. Am. Ass. Petrol. Geol. 35, 1-14.

Dorning, K. J. 1987: The organic palaeontology of Palaeozoic carbonate environments. In Hart, M. B. (edit.) Micropalaeontology of carbonate environments, 256-265. Chichester, England: Ellis Horwood Ltd.

Dow, W. G. 1977: Kerogen studies and geological interpretations. J. geochem. Expl. 7, 79-99.

Duffield, S. L. 1985: Land-derived microfossils from the Jupiter Formation (Upper Llandoverian) Anticosta Island, Québec. J. Paleont. 59, 1005-1010.

Durand, B. (edit.) 1980: Kerogen. Insoluble organic matter from sedimentary rocks, 519 pp. Paris: Editions Technip.

Ellitsgaard-Rasmussen, K. 1955: Features of the geology of the folding range of Peary Land, North Greenland. Meddr Grønland 127(7), $56 \mathrm{pp}$.

Embry, A. F., Powell, T. C. \& Mayr, U. in press: Petroleum resources, Arctic Islands. A. Petroleum. In Trettin, H. P. (edit.) The Innuitian Orogen and Arctic platform: Canada and Greenland. The geology of North America E. Ottawa: Geological Survey of Canada.

Epstein, A. G., Epstein, J. B. \& Harris, L. D. 1977: Conodont color alteration - an index to metamorphism. Prof. Pap. U.S. geol. Surv. 995, 27 pp. 
Epstein, S., Buchsbaum, R., Lowenstam, H. A. \& Urey, H. C. 1951: Carbonate-water isotopic temperature scale. Bull. geol. Soc. Am. 62, 417-425.

Escher, J. C. \& Larsen P.-H. 1987: The buried western extension of the Navarana Fjord escarpment in central and western North Greenland. Rapp. Gronlands geol. Unders. 133, 81-89.

Espitalié, J., Laporte, J. L., Madec, M., Marquis, F., Leplat, P. 1977: Methode rapide de caracterisation des roches mères de leur potentiel pétrolier et de leur degré d'évolution. Revue Inst. fr. Pétrole 32, 23-42.

Espitalié, J., Madec, M. \& Tissot, B. 1980: Role of mineral matrix in kerogen pyrolysis: influence on petroleum generation and migration. Bull. Am. Ass. Petrol. Geol. 64, 59-66.

Espatilié, J., Makadi, K. S. \& Trichet, Y. 1984: Role of the mineral matrix during kerogen pyrolysis. Org. Geochem. 6, 365-382.

Evans, R. J. \& Felbeck, Jr. G. T. 1983: High temperature simulation of petroleum formation - II. Effects of inorganic sedimentary constituents on hydrocarbon formation. Org. Geochem. 4, 145-152.

Folk, R. L. 1968: Petrology of sedimentary rocks, 170 pp. Austin, Texas: Hemphill's.

Forsberg, A. \& Bjorøy, M. 1983: A sedimentological and organic geochemical study of the Botneheia Formation, Svalbard, with special emphasis on the effects of weathering on the organic matter in shales. In Bjorøy, M. et al. (edit.) Advances in organic geochemistry 1981, 60-68. London: Wiley \& sons Ltd.

Foscolos, A. E., Powell, T. G. \& Gunther, P. R. 1976: The use of clay minerals and inorganic and organic geochemical indicators for evaluating the degrec of diagenesis and oil generating potential of shales. Geochim. cosmochim. Acta $\mathbf{4 0}$, 953-966.

Friderichsen, J. D. \& Bengaard, H.-J. 1985: The North Greenland fold belt in eastern Nansen Land. Rapp. Grønlands geol. Unders. 126, 69-78.

Friderichsen, J. D., Higgins, A. K., Hurst, J. M., Pedersen, S. A. S., Soper, N. J. \& Surlyk, F. 1982: Lithostratigraphic framework of the Upper Proterozoic and Lower Palaeozoic deep water clastic deposits of North Greenland. Rapp. Gronlands geol. Unders. 107, $20 \mathrm{pp}$.

Frisch, T. 1974: Metamorphic and plutonic rocks of northernmost Ellesmere Island, Canadian Arctic Archipelago. Bull. geol. Surv. Can. 229, 87 pp.

Galimov, E. M. 1980: ${ }^{13} \mathrm{C} /{ }^{12} \mathrm{C}$ in kerogen. In Durand, B. (edit.) Kerogen, 271-300. Paris: Editions Technip.

Gleadow, A. J. W. \& Lovering, J. F. 1978: Thermal history of granitic rocks from western Victoria: a fission track dating study. J. Geol. Soc. Aust. 25, 323-340.

Gleadow, A. J. W., Duddy, I. R. \& Lovering, J. F. 1983: Fission track analysis: a new tool for the evaluation of thermal histories and hydrocarbon potential. Austr. Petrol. Expl. Assoc. J. 23, 93-102.

Gleadow, A. J. W., Duddy, I. R., Green, P. F. \& Lovering, J. F. 1986: Confined fission track lengths in apatite: a diagnostic tool for thermal history. Contr. Mineral. Petrol. 94, $405-415$.
Glensen, P. G. \& Andrews, H. N. 1987: The evolution of early land plants. American Scientist 75, 478-489.

Glickson, M., Gibson, D. L. \& Philp, R. P. 1985: Organic matter in Australian Cambrian oil shales and Lower Palaeozoic shales. Chem. Geol. 51, 175-191.

Goodarzi, F. \& Norford, B. S. 1985: Graptolites as indicators of the temperature history of rocks. J. geol. Soc. Lond. 142, 1089-1099.

Goodarzi, F., Snowdon, L. R., Gunther, P. R. \& Jenkins, W. A. M. 1985: Preliminary organic petrography of Palaeozoic rocks from the Grand Banks, Newfoundland. Marine Petrol. Geol. 2, 254-259.

Grahn, Y. \& Nøhr-Hansen, H. 1989: Chitinozoans from Ordovician and Silurian shelf and slope sequences from North Greenland. Rapp. Grønlands geol. Unders. 144.

Grantham, P. J. 1986: The occurrence of unusual $C_{27}$ and $C_{29}$ sterane predominance in two types of Oman crude oil. Org. Geochem. 9, 1-10.

Grønlands Fiskeri- og Miljøundersøgelser 1986: Biologiske miljøundersøgelser i Nordgrønland 1984-85. Unpubl. rep., 113 pp.

Gutjahr, C. C. M. 1983: Introduction to incident-light microscopy of oil and gas source rocks. Geol. Mijnbouw 62, 417425 .

Håkansson, E. \& Stemmerik, L. 1984: Wandel Sea Basin-The North Greenland equivalent to Svalbard and the Barents Shelf. In Spencer, A. M. et al. (edit.) Petroleum geology of North European margin, 97-107. Norwegian Petroleum Society.

Hansen, B. T., Kalsbeek, F. \& Holm, P. M. 1987: Archaean age and Proterozoic metamorphic overprinting of the crystalline basement at Victoria Fjord, North Greenland. Rapp. Grønlands geol. Unders. 133, 159-168.

Hansen, K. 1985: Fission track age determinations of vertical movements in the crust caused by continental rifting: a fission track age study of the Scoresby Sund area; method and results. Unpublished lic.scient. thesis, Univ. Copenhagen, 119 pp.

Hatch, J. R., Jacobsen, S. R., Witzke, B. J., Risatti, J. B., Anders, D. E., Watney, W. L., Newell, K. D. \& Vuletich, A. K. 1987: Possible late Middle Ordovician organic carbon isotope excursion: evidence from Ordovician oils and hydrocarbon source rocks, Mid-Continent and East-Central United States. Bull. Am. Ass. Petrol. Geol. 71, 1342-1354.

Henderson, G. 1976: Petroleum geology. In Escher, A. \& Watt, W. S. (edit.) Geology of Greenland, 489-505. Copenhagen: Geol. Surv. Greenland.

Henriksen, N. 1985a: Systematic 1:500 000 mapping and regional geological studies in central and western North Greenland. Rapp. Grønlands geol. Unders. 125, 9-17.

Henriksen, N. 1985b: Systematic geological mapping in 1984 in central and western North Greenland. Rapp. Grønlands geol. Unders. 126, 5-10.

Henriksen, N. 1986: Completion of field work for the 1:500 000 mapping and regional geological studies in central and western North Greenland. Rapp. Gronlands geol. Unders. 130, 9-17.

Henriksen, N. 1987: Systematic geological mapping in 1985 in 
central and western North Greenland. Rapp. Grønlands geol. Unders. 133, 5-12.

Henriksen, N. \& Jepsen, H. F. 1985: Precambrian crystalline basement at the head of Victoria Fjord, North Greenland. Rapp. Grønlands geol. Unders. 126, 11-16.

Henriksen, N. \& Peel, J. S. 1976: Cambrian - Early Ordovician stratigraphy in southwestern Washington Land, western North Greenland. Rapp. Grønlands geol. Unders. 80, 17-23.

Heroux, Y. Chagnon, A. \& Bertrand, R. 1979: Compilation and correlation of major thermal maturation indicators. Bull. Am. Ass. Petrol. Geol. 63, 2128-2144.

Higgins, A. K. 1986: Geology of central and eastern North Greenland. Rapp. Grønlands geol. Unders. 128, 37-54.

Higgins, A. K. \& Soper, D. J. 1985: Cambrian - Lower Silurian slope and basin stratigraphy between northern Nyeboe Land and western Amundsen Land, North Greenland. Rapp. Grønlands geol. Unders. 126, 79-86.

Higgins, A. K., Mayr, U. \& Soper, N. J. 1982: Fold belts and metamorphic zones of northern Ellesmere Island and North Greenland. Rapp. Grønlands geol. Unders. 130, 9-17.

Higgins, A. K., Soper, N. J. \& Friderichsen, J. D. 1985: North Greenland fold belt in eastern North Greenland. In Gee, D. G. \& Sturt, B. A. (edit.) The Caledonide Orogen - Scandinavia and related areas, 1017-1029. London: John Wiley \& Sons Ltd.

Higgins, A. K., Ineson, J. R., Peel, J. S., Surlyk, F. \& Sønderholm, M. in press: The Franklinian basin in North Greenland. In Trettin, H. P. (edit.) The Innuitian Orogen and Arctic platform: Canada and Greenland. The geology of North America E. Ottawa: Geological Survey of Canada.

Hills, I. R., Whitehead, E. V., Anders, D. E., Cummins, J. J. \& Robinson, W.E. 1966: An optically active triterpane, gammacerane in Green River, Colorado, oil shale bitumen. Chem. Commun. 20, 752-754.

Horsfield, B. 1984: Pyrolysis studies and petroleum exploration. In Brooks, J. \& Welte, D. (edit.) Advances in petroleum geochemistry 1, 247-298. London: Academic Press.

Horsfield, B., Dembicki Jr, H. \& Ho, T. T. Y. 1983: Some potential applications of pyrolysis to basin studies. J. geol. Soc. Lond. 140, 431-443.

Huang, W.-Y. \& Meinschein, W. G. 1976: Sterols as ecological indicators. Geochim. cosmochim. Acta 40, 323-330.

Hunt, J. M. 1979: Petroleum geochemistry and geology, 615 pp. San Francisco: W. H. Freeman and Co.

Hurford, A. J. 1986: Cooling and uplift patterns in the Lepontine Alps, South Central Switzerland and an age of the vertical movement on the Insubric fault line. Contrib. Miner. Petrol. 92, 413-427.

Hurford, A. J. \& Green, P. F. 1983: The zeta age calibration of fission track dating. Isotope Geosci. 1, 285-317.

Hurst, J. M. 1980a: Silurian stratigraphy and facies distribution in Washington Land and western Hall Land, North Greenland. Bull. Grønlands geol. Unders. 138, 95 pp.

Hurst, J. M. 1980b: Paleogeographic and stratigraphic differentiation of Silurian buildups and biostromes of North Greenland. Bull. Am. Ass. Petrol. Geol. 64, 527-548.

Hurst, J. M. 1981: Platform edge and slope relationships:
Silurian of Washington Land, North Greenland and comparison to Arctic Canada. Bull. Can. Petrol. Geol. 29, 408-419.

Hurst, J. M. 1984: Upper Ordovician and Silurian carbonate shelf stratigraphy, facies and evolution, eastern North Greenland. Bull. Grønlands geol. Unders. 148, 73 pp.

Hurst, J. M. \& Peel, J. S. 1979: Late Proterozoic (?) to Silurian stratigraphy of southern Wulff Land, North Greenland. Rapp. Grønlands geol. Unders. 91, 37-56.

Hurst, J. M. \& Surlyk, F. 1982: Stratigraphy of the Silurian turbidite sequence of North Greenland. Bull. Grønlands geol. Unders. 145, $121 \mathrm{pp}$.

Hurst, J. M. \& Surlyk, F. 1983: Initiation, evolution and destruction of an early Paleozoic carbonate shelf, eastern North Greenland. J. Geol. 91, 671-691.

Hurst, J. M., McKerrow, W. S., Soper, N. J. \& Surlyk, F. 1983: The relationship between Caledonian nappe tectonics and Silurian turbidite deposition in North Greenland. $J$. geol. Soc. Lond. 140, 123-132.

Illich, H. A. 1983: Pristane, phytane, and lower molecular weight isoprenoid distributions in oils. Bull. Am. Ass. Petrol. Geol. 67, 385-397.

Ineson, J. R. 1985: The stratigraphy and sedimentology of the Brønlund Fjord and Tavsen Iskappe Groups (Cambrian) of Peary Land, eastern North Greenland. Unpublished Ph.D. thesis, University of Keele, U.K., $310 \mathrm{pp}$.

Ineson, J. R. \& Peel, J. S. 1980: Cambrian stratigraphy in Peary Land, eastern North Greenland. Rapp. Gronlands geol. Unders. 99, $33-42$.

Ineson, J. R. \& Peel, J. S. 1987: Cambrian platform - outer shelf relationship in the Nordenskiöld Fjord region, central North Greenland. Rapp. Grønlands geol. Unders. 133, 13-26.

Ineson, J. R. \& Peel, J. S. in press: Cambrian shelf stratigraphy of the Peary Land region, central North Greenland. Bull. Grønlands geol. Unders.

Jacob, H. 1983: Recent studies on the genesis of natural solid oil bitumens. Geol. Jahr. Reihe D 59,61 pp.

Jacob, H. 1985: Disperse, feste Erdölbitumina als Migrationsund Maturitätsindikatoren im Rahmen der Erdöl-/ErdgasProspektion. Eine Modellstudie in NW-Deutschland. Deutsche Gesellschaft Mineralölwissenschaft und Kohlechemie E.V., Forschungsbericht 267, $54 \mathrm{pp}$.

Jensenius, J. 1987: Fluid inclusion and stable isotope studies of diagenctic calcite and dolomite associated with seeping asphalt, North Greenland, 28 pp. In Jensenius, J. 1987: Fluid inclusion microthermometry and stable isotope studies applied to the diagenesis of sedimentary rocks. Unpublished lic. scient. thesis, University of Copenhagen.

Jepsen, H. F. 1971: The Precambrian, Eocambrian and early Palaezoic stratigraphy of the Jørgen Brønlund Fjord area, Peary Land, North Greenland. Bull. Grønlands geol. Unders. 96, 42 pp.

Jones, R. W. 1987: Organic facies. In Brooks, J. (edit.) Advances in petroleum geochemistry 2, 1-90. London: Academic Press.

Katz, B. J. 1983: Limitations of 'Rock-Eval' pyrolysis for typing organic matter. Org. Geochem. 4, 195-199.

Kerr, J. W. 1967: Nares submarine rift valley and relative 
rotation of North Greenland. Bull. Can. Petrol. Geol. 15, 483-520.

Kerr, J. W. 1980: A plate tectonic contest in Arctic Canada. In Strangway, D. W. (edit.) The continental crust and its mineral deposits. Spec. Pap. geol. Ass. Can. 20, 457-486.

Kingston, D. R., Dishroon, C. P. \& Williams, P. A. 1985: Global basin classification system. Oil Gas J. 83(18), 238262.

Kisch, H. J. 1980: Incipient metamorphism of Cambro-Silurian clastic rocks from the Jamtland Supergroup, central Scandinavian caledonides, western Sweden: illite crystallinite and 'vitrinite' reflectance. J. geol. Soc. Lond. 137, 271-288.

Klemme, H. D. 1971: What giants and their basins have in common. Oil Gas J. 69(9), 85-90.

Koch, C. J. W. 1987: Preparation and characterization by $\mathrm{X}$-ray diffraction of kerogen from Cambrian and Silurian sedimentary rocks from North Greenland. Unpubl. intern. GGU rep., 13 pp.

Koch, L. 1925: The geology of North Greenland. Am. J. Sci. 9, 271-285.

Koch, L. 1929: Stratigraphy of Greenland. Meddr Grønland 73(2), 205-320.

Kontorovich, A. E. 1984: Geochemical methods for the quantitative evaluation of the petroleum potential of sedimentary basins. In Demaison, G. \& Murris, R. J. (edit.) Petroleum geochemistry and basin evaluation. Mem. Am. Ass. Petrol. Geol. 35, 79-109.

Krebs, W. \& Macqueen, R. W. 1984: Sequence of diagenetic and mineralization events, Pine-Point lead-zinc property, Northwest Territories, Canada. Bull. Can. Petrol. Geol. 32, 434-464.

Larsen, N. H. 1985: Cambrian endolithic alga from North Greenland. Sec. Int. Phycol. Congr., Book of abstracts, 88. Copenhagen.

Larsen, N. H. 1989: Fossil algae from North Greenland. Open File Ser. Grønlands geol. Unders. 89/3, 32 pp. +42 figs.

Larsen, O. 1982: The age of the Kap Washington Group volcanics, North Greenland. Bull. geol. Soc. Denmark 31, 49-55.

Larsen, O., Dawes, P. R. \& Soper, N. J. 1978: Rb/Sr age of the Kap Washington Group, Peary Land, North Greenland, and its geotectonic implications. Rapp. Grønlands geol. Unders. 90, 115-119.

Larsen, P.-H. \& Escher, J. C. 1985: The Silurian turbidite sequence of the Peary Land Group between Newman Bugt and Victoria Fjord, western North Greenland. Rapp. Grønlands geol. Unders. 126, 47-67.

Larsen, P.-H. \& Escher, J. C. 1987: Additions to the lithostratigraphy of the Peary Land Group (Silurian) in western and central North Greenland. Rapp. Gronlands geol. Unders. 133, 65-80.

Larsen, P.-H., Edwards, D. \& Escher, J. C. 1987: Late Silurian plant megafossils from the Peary Land Group, North Greenland. Rapp. Grønlands geol. Unders. 133, 107-112.

Legall, F. D., Barnes, C. R. \& Macqueen, R. W. 1981: Thermal maturation, burial history and hotspot development, Paleozoic strata of southern Ontario-Québec, from cono- dont and acritarch colour alteration studies. Bull. Can. Petrol. Geol. 29, 492-539.

Leggett, J. K., McKerrow, W. S., Cocks, L. R. M. \& Richards, R. B. 1981: Perodicity in the early Palaeozoic marine realm. J. geol. Soc. Lond. 138, 167-176.

Lewan, M. D. 1983: Effects of thermal maturation on stable organic carbon isotopes as determined by hydrous pyrolysis of Woodford Shale. Geochim. cosmochim. Acta 47, 14711479.

Lewan, M. D. 1986: Stable carbon isotopes of amorphous kerogens from Phanerozoic rocks. Geochim. cosmochim. Acta 50, 1583-1591.

Leythaeuser, D. 1973: Effects of weathering on organic matter in shales. Geochim. cosmochim. Acta 37, 113-120.

Link, W. K. 1952: Significance of oil and gas seeps in World oil exploration. Bull. Am. Ass. Petrol. Geol. 36, 1505-1540.

Macauley, G., Snowdon, L. R. \& Ball, F. D. 1985: Geochemistry and geological factors governing exploitation of selected Canadian oil shale deposits. Pap. geol. Surv. Can. 85-13, 65 pp.

Mackenzie, A. G. 1984: Applications of biological markers in petroleum geochemistry. In Brooks, J. \& Welte, D. H. (edit.) Advances in petroleum geochemistry 1, 115-214. London: Academic Press.

Macqueen, R. W. \& Powell, T. G. 1983: Organic geochemistry of the Pine Point lead-zinc ore field and region, Northwest Territories, Canada. Econ. Geol. 78, 1-15.

Marcussen, C., Christiansen, F. G., Larsen, P.-H., Olsen, H., Piasecki, S., Stemmerik, L., Bojesen-Koefoed, J., Jepsen, H. F. \& Nøhr-Hansen, H. 1987: Studies of the onshore hydrocarbon potential in East Greenland 1986-87: field work from $72^{\circ}$ to $74^{\circ} \mathrm{N}$. Rapp. Grønlands geol. Unders. 135, 72-81.

McKerrow, W. S. 1979: Ordovician and Silurian changes in sea level. J. geol. Soc. Lond. 136, 137-145.

McKirdy, D. M., Aldridge, A. K. \& Ypma, P. J. M. 1983: A geochemical comparison of some crude oils from Pre-Ordovician carbonate rocks. In Bjoroy, M. et al. (edit.) Advances in organic geochemistry 1981, 99-107. London: Wiley \& Sons Ltd.

McKirdy, D. M., Kantsler, A. J., Emmett, J. K. \& Aldridge, A. K. 1984: Hydrocarbon genesis and organic facies in Cambrian carbonates of the eastern Officer basin, South Australia. In Palacas, J. G. (edit.) Petroleum geochemistry and source rock potential of carbonate rocks. Am. Ass. Petrol. Geol. Stud. Geol. 18, 13-31.

Miller, B. M. 1986: Resource appraisal methods, choice and outcome. In Rice, D. D. (edit.) Oil and gas assessment. Am. Ass. Petrol. Geol. Stud. Geol. 21, 1-23.

Moldowan, J. M. Seifert, W. K. \& Gallegos, E. J. 1985: Relationship between petroleum composition and depositional environment of petroleum source rocks. Bull. Am. Ass. Petrol. Geol. 69, 1255-1268.

Moore, L. V. 1984: Significance, classification of asphaltic material in petroleum exploration. Oil Gas J. 82(41), 109 112 .

Nassichuk, W. W. 1983: Petroleum potential in Arctic North 
America and Greenland. Cold Regions Science and Technology 7, 51-88.

Nielsen, E. 1941: Remarks on the map and the geology of Kronprins Christians Land. Meddr Grønland 126(2), 34 pp.

Norford, B. S. 1972: Silurian stratigraphic sections at Kap Tyson, Offley $\emptyset$ and Kap Schuchert, northwestern Greenland. Meddr Grønland 195(2), 40 pp.

Nøhr-Hansen, H. \& Koppelhus, E. B. 1988: Ordovician spores with trilete rays from Washington Land, North Greenland. Rev. Palaeobot. Palynol. 56, 305-311.

O'Connor, B. 1979: The Portfjeld Formation (?early Cambrian) of eastern North Greenland. Rapp. Grønlands geol. Unders. 88, 23-28.

Ogunyami, O., Hesse, R. \& Héroux, Y. 1980: Pre-orogenic and synorogenic diagenesis and anchimetamorphism in Lower Paleozoic continental margin sequences of the northern Appalachians in and around Quebec City, Canada. Bull. Can. Petrol. Geol. 28, 559-577.

Ourisson, G., Albrecht, P. \& Rohmer, M. 1979: Paleochemistry and biochemistry of a group of natural products: the hopanoids. Pure Appl. Chem. 51, 709-729.

Østfeldt, P. 1987a: Oil-source rock correlation in the Danish North Sea. In Brooks, J. \& Glennie, K. (edit.): Petroleum geology of North West Europe, 419-429. London: Graham \& Trotman.

Østfeldt, P. 1987b: Organic geochemistry of North Greenland samples. Unpubl. intern. GGU rep., 43 pp.

Parrish, J. T. 1982: Upwelling and petroleum source beds, with reference to Paleozoic. Bull. Am. Ass. Petrol. Geol. 66, $750-774$.

Parrish, J. T. 1987: Palaeo-upwelling and the distribution of organic-rich rocks. In Brooks, J. \& Fleet, A. J. (edit.) Marine petroleum source rocks. Spec. Publ. geol. Soc. Lond. 26, 199-205.

Peel, J. S. 1979: Cambrian-Middle Ordovician stratigraphy of the Adams Gletscher region, south-west Peary Land, North Greenland. Rapp. Grønlands geol. Unders. 88, 29-39.

Peel, J. S. 1980: Cambrian and Ordovician geology of Warming Land and southern Wulff Land, central North Greenland. Rapp. Grønlands geol. Unders. 101, 55-60.

Peel, J. S. 1982: The Lower Paleozoic of Greenland. In Embry, A. F. \& Balkwill, H. R. (edit.) Arctic geology and geophysics. Mem. Can. Soc. Petrol. Geol. 8, 309-330.

Peel, J. S. 1985: Cambrian - Silurian platform stratigraphy of eastern North Greenland. In Gee, D. G. \& Sturt, B. A. (edit.) The Caledonide Orogen - Scandinavia and related areas, 1077-1094. London: John Wiley \& Sons Ltd.

Peel, J. S. \& Christie, R. L. 1982: Cambrian-Ordovician stratigraphy, correlations around Kane basin. In Dawes, P. R. \& Kerr, J. W. (edit.) Nares Strait and the drift of Greenland: a conflict in plate tectonics. Meddr Grønland Geosci. 8, 117135.

Peel, J. S. \& Hurst, J. M. 1980: Late Ordovician and early Silurian stratigraphy of Washington Land, western North Greenland. Rapp. Gronlands geol. Unders. 100, 18-24.

Peel, J. S. \& Wright, S. C. 1985: Cambrian platform stratigraphy in the Warming Land - Freuchen Land region, North Greenland. Rapp. Grønlands geol. Unders. 126, 17-24.
Peel, J. S., Dawes, P. R., Collinson, J. D. \& Christie, R.L. 1982: Proterozoic - basal Cambrian stratigraphy across Nares Strait: correlation between Inglefield Land and Bache Peninsula. In Dawes, P. R. \& Kerr, J. W. (edit.) Nares Strait and the drift of Greenland: a conflict in plate tectonics. Meddr Grønland Geosci. 8, 105-115.

Perregaard, J. 1979: Organic geochemistry of sedimentary organic matter from Greenland: a petroleum source rock evaluation. Unpubl. intern. GGU rep., 81 pp. + appendix.

Philp, R. P. \& Lewis, C. A. 1987: Organic geochemistry of biomarkers. Ann. Rev. Earth Planet. Sci. 15, 363-395.

Poty, B., Leroy, J. \& Jachimowicz, 1976: A new device for measuring temperatures under microscope: the Chaixmeca microthermometry apparatus. In Roedder, E. \& Kozlowski, A. (edit) Fluid inclusion research 9, 173-178.

Powell, T. G. 1978: An assessment of the hydrocarbon source potential of the Canadian Arctic Island. Pap. geol. Surv. Can. 78-12, 82 pp.

Powell, T. G., Macqueen, R. W., Barker, J. F. \& Bree, D. G. 1984: Geochemical character and origin of Ontario oils. Bull. Can. Petrol. Geol. 32, 289-312.

Procter, R. M., Tayor, G. C. \& Wade, J. A. 1984: Oil and gas resources of Canada. Pap. geol. Surv. Can. 83-31, 59 pp.

Radke, B. M. \& Mathis, R. L. 1980: On the formation and occurrence of saddle dolomite. J. sed. Petrol. 50, 1149-1168.

Rayer, F. G. 1981: Exploration prospects and future petroleum potential of the Canadian Arctic Islands. J. petrol. Geol. 3, $367-412$.

Reed, J. D., Illich, H. A. \& Horsfield, B. 1986: Biochemical evolutionary significance of Ordovician oils and their sources. In Leythaeuser, D. \& Rullkötter, J. (edit.) Advances in organic geochemistry 1985. Org. Geochem. 10, 347-358.

Rice, D. D. (edit.) 1986: Oil and gas assessment. Am. Ass. Petrol. Geol. Stud. Geol. 21, 267 pp.

Robert, P. 1974: Analyse microscopique des charbons et des bitumen dispersés dans roches et mesure de leur pouvoir réflecteur. Application à l'étude de la paléogéothermie des bassins sédimentaires et de la genèse des hydrocarbures. In Tissot, B. \& Bienner, F. (edit.) Advanced organic geochemistry, 549-569. Rueil-Malmaison.

Rogers, M. A., McAlary, J. D. \& Baily, N. J. L. 1974: Significance of reservoir bitumens to thermal-maturation studies, Western Canada basin. Bull. Am. Ass. Petrol. Geol. 58, 1806-1824.

Rolle, F. 1981: Hydrocarbon source rock sampling in Peary Land 1980. Rapp. Grønlands geol. Unders. 106, 99-103.

Rolle, F. \& Wrang, P. 1981: En foreløbig oliegeologisk vurdering af Peary Land området i Nordgrønland. Unpubl. intern. GGU rep., 21 pp.

Rullkötter, J., Meyers, P. A., Schaefer, R. G. \& Dunham, K. W. 1986: Oil generation in the Michigan Basin: a biological marker and carbon isotope approach. In Leythaeuser, D. \& Rullkötter, J. (edit.) Advances in organic geochemistry 1985. Org. Geochem. 10, 359-375.

St. John, B., Bally, A. W. \& Klemme, H. D. 1984: Sedimentary provinces of the world - hydrocarbon productive 
and nonproductive. Am. Assoc. Petrol. Geol. Map Library, 36 pp. + maps.

Schoell, M. 1984: Wasserstoff- und Kohlenstoffisotope in organischen Substanzen, Erdölen und Erdgassen. Geol Jahrb. Reihe D. 67, 167 pp.

Schopf, T. J. M. 1983: Paleozoic black shales in relation to continental margin upwelling. In Thiede, J. \& Suess, E. (edit.) Coastal upwelling, its sediment record, part B: Sedimentary records of ancient coastal upwelling, 570-596. New York: Plenum Press.

Scotese, C. R., Bambach, R. K., Barton, C., Van der Voo, R. \& Ziegler, A. M. 1979: Palaeozoic base maps. J. Geol. 87 , 217-278.

Sikander, A. H. \& Pittion, J. L. 1978: Reflectance studies on organic matter in Lower Paleozoic sediments of Quebec. Bull. Can. Petrol. Geol. 26, 132-151.

Sluijk, D. \& Nederlof, M. H. 1984: Worldwide geological experience as a systematic basis for prospect appraisal. In Demaison, G. \& Murris, R. J. (edit.) Petroleum geochemistry and basin evaluation. Mem. Am. Ass. Petrol. Geol. 35, 15-26.

Smith, M. P., Sønderholm, M. \& Tull, S. J. 1989: The Morris Bugt Group (Middle Ordovician - Early Silurian) of North Greenland and its correlatives. Rapp. Grønlands geol. Unders. 143.

Sønderholm, M. \& Due, P. H. 1985: Lower and Middle Ordovician platform carbonate lithostratigraphy of Warming Land, Wulff Land and Nares Land, North Greenland. Rapp. Grønlands geol. Unders. 126, 31-46.

Sønderholm, M. \& Harland, T. L. 1989a: Franklinian reef belt, Silurian, North Greenland. In Geldsetzer, H. J. J., James, N. P. \& Tebbutt, G. E. (edit.) Reefs, Canada and adjacent area. Mem. Can. Soc. Petrol. Geol. 13, 356-366.

Sønderholm, M. \& Harland, T. L. 1989b: Latest Ordovicianearliest Silurian reef mounds in western North Greenland. In Geldsetzer, H. J. J., James, N. P. \& Tebbutt, G. E. (edit.) Reefs, Canada and adjacent area. Mem. Can. Soc. Petrol. Geol. 13, 241-243.

Sønderholm, M., Harland, T. L., Due, P. H., Jørgensen, L. N. \& Peel, J. S. 1987: Lithostratigraphy and depositional history of Upper Ordovician - Silurian shelf carbonates in central and western North Greenland. Rapp. Grønlands geol. Unders. 133, 27-40.

Soper, N. J. \& Higgins, A. K. 1987: A shallow detachment beneath the North Greenland fold belt: implications for sedimentation and tectonics. Geol. Mag. 124, 441-450.

Soper, N. J., Dawes, P. R. \& Higgins, A. K. 1982: CretaceousTertiary magmatic and tectonic events in North Greenland and the history of adjacent ocean basins. In Dawes, P. R. \& Kerr, J. W. (edit.) Nares Strait and the drift of Greenland: a conflict in plate tectonics. Meddr Grønland Geosci. 8, 205220.

Springer, N. 1981: Preliminary Rb-Sr age determinations from the North Greenland fold belt, Johannes V. Jensen Land, with comments on the metamorphic grade. Rapp. Grønlands geol. Unders. 106, 77-84.

Springer, N. (compiler) 1987: Conventional core analysis for
GGU. Cambrian sandstones from North Greenland (Nordolie). Unpubl. intern. GGU rep., 17 pp.

Sproule, J. C. 1966: Oil and gas prospects of the Canadian Arctic Islands. Proc. 8th Commonwealth Mining and Metallurgical Congress, Australia and New Zealand 1965, Vol. 5 (Petroleum), 57-64.

Staplin, F. L. 1969: Sedimentary organic matter, organic metamorphism, and oil and gas occurrence. Bull. Can. Soc. Petrol. Geol. 17, 47-66.

Stemmerik, L. \& Håkansson, E. 1989: Stratigraphy and depositional history of the Upper Palaeozoic and Triassic sediments in the Wandel Sea Basin, eastern North Greenland. Rapp. Grønlands geol. Unders. 143.

Stoneley, R. 1981: Petroleum: the sedimentary basin. In Tarling, D. H. (edit.) Economic geology and geotectonics, 51-71. London: John Wiley \& Sons Ltd.

Stouge, S., Thomsen, E. \& Guvad, C. 1988: Reflected light microscopy of graptolite periderm material of Ordovician/ Silurian strata in North Greenland. Unpubl. intern. GGU rep., 58 pp.

Strother, P. K. \& Traverse, A. 1979: Plant microfossils from Llandoverian and Wenlockian rocks of Pennsylvania. Palynology 3, 1-21.

Stuart-Smith, J. H. 1970: Hydrocarbon potential of northern Greenland. Bull. Am. Ass. Petrol. Geol. 54, 2507 only.

Stuart-Smith, J. H. \& Wennekers, J. H. N. 1977: Geology and hydrocarbon discoveries of Canadian Arctic Islands. Bull. Am. Ass. Petrol. Geol. 61, 1-27.

Surlyk, F. 1982: Nares Strait and the down-current termination of the Silurian turbidite basin of North Greenland. In Dawes, P. R. \& Kerr, J. W. (edit.) Nares Strait and the drift of Greenland: a conflict in plate tectonics. Meddr Grønland Geosci. 8, 147-150.

Surlyk, F. 1983: Source rock sampling, stratigraphical and sedimentological studies in the Upper Palaeozoic of the Jameson Land basin, East Greenland. Rapp. Grønlands geol. Unders. 115, 88-93.

Surlyk, F. \& Hurst, J. M. 1983: Evolution of the early Paleozoic deep-water basin of North Greenland - aulacogen or narrow ocean? Geology 11, 77-81.

Surlyk, F. \& Hurst, J. M. 1984: The evolution of the early Paleozoic deep-water basin of North Greenland. Bull. geol. Soc. Am. 95, 131-154.

Surlyk, F., Hurst, J. M., Marcussen, C., Piasecki, S., Rolle, F., Scholle, P. A., Stemmerik, L. \& Thomsen, E. 1984: Oil geological studies in the Jameson Land basin, East Greenland. Rapp. Grønlands geol. Unders. 120, 85-90.

Surlyk, F. \& Ineson, J. R. 1987a: Aspects of Franklinian shelf, slope and trough evolution and stratigraphy of North Greenland. Rapp. Gronlands geol. Unders. 133, 41-58.

Surlyk, F. \& Ineson, J. R. 1987b: The Navarana Fjord Member (new) - an Upper Llandovery platform derived carbonate conglomerate. Rapp. Grønlands geol. Unders. 133, 59-63.

Thickpenny, A. \& Leggett, J. K. 1987: Stratigraphic distribution and palaeo-oceanographic significance of European early Palaeozoic organic-rich sediments. In Brooks, J. \& 
Fleet, A. J. (edit.) Marine petroleum source rocks. Spec. Publ. geol. Soc. Lond. 26, 231-247.

Thomsen, E. \& Guvad, C. 1987: Organic petrology and thermal maturity of Lower Palaeozoic deposits from western and central North Greenland. Unpubl. intern. GGU rep., part 1 (text) $40 \mathrm{pp}$. and part 2 (figures) $49 \mathrm{pp}$

Tissot, B. P. \& Welte D. H. 1984: Petroleum formation and occurrence, 699 pp. Berlin, Heidelberg, New York, Tokyo: Springer Verlag.

Trettin, H. P. 1987: Pearya: a composite terrane with Caledonian affinities in northern Ellesmere Island. Can. J. Earth Sci. 24, 224-245.

Trettin, H. P. \& Balkwill, H. R. 1979: Contributions to the tectonic history of the Innuitian Province, Arctic Canada. Can. J. Earth Sci. 16, 748-769.

Trettin, H. P., Frisch, T. O., Sobczak, L. W., Weber, J. R., Law, L. R., Delaurier, I., Niblett, E. R. \& Whitnam, K. 1972: The Innuitian Province. In Price, R. A. \& Douglas, R. J. W. (edit.) Variation in tectonic styles in Canada. Spec. Pap. geol. Ass. Can. 11, 83-179.

Troelsen, J. C. 1949: Contributions to the geology of the area round Jørgen Brønlunds Fjord, Peary Land, North Greenland. Meddr Grønland 149(2), 29 pp.

Troelsen, J. C. 1950: Contributions to the geology of Northwest Greenland, Ellesmere Island and Axel Heiberg Island. Meddr Grønland 149(7), 85 pp.

Tyson, R. V. 1987: The genesis and palynofacies characteristics of marine petroleum source rocks. In Brooks, J. \& Fleet, A. J. (edit.) Marine petroleum source rocks. Spec. Publ. geol. Soc. Lond. 26, 47-67.
Ungerer, P., Bessis, F., Chenet, P. Y., Durand, B., Nogaret, A., Chiarelli, A., Oudin, J. L. \& Perrin, J. F. 1984: Geological and geochemical models in oil exploration; principles and practical examples. In Demaison, G. \& Murris, R. J. (edit.) Petroleum geochemistry and basin evaluation. Mem. Am. Ass. Petrol. Geol. 35, 53-77.

Vavrdová, N. 1984: Some plant microfossils of possible terrestrial origin from the Ordovician of Central Bohemia. Věstnik Ústředniho ústavu geologického 59, 165-170.

Venkatachala, B. S. 1981: Differentiation of amorphous organic matter types in sediments. In Brooks, J. (edit.) Organic maturation studies and fossil fuel exploration, 177-200. London: Academic Press.

Waples, D. W. 1985: Geochemistry in petroleum exploration, 232 pp. Dordrecht: Reidel Publ. Com.

Wedeking, K. W. \& Hayes, J. M. 1983: Carbonization of Precambrian kerogens. In Bjorøy et al. (edit.) Advances in organic geochemistry 1981, 546-553. London: Wiley \& Sons Ltd.

Welte, D. H., Kalkreuth, W. \& Hoefs, J. 1975: Age-trend in carbon isotopic composition in Palaeozoic sediments. Naturwissenschaften 62, 482-483.

Welte, D. H. \& Yukler, M. A. 1981: Petroleum origin and accumulation in basin evolution - a quantitative model. Bull. Am. Ass. Petrol. Geol. 65, 1387-1396.

Yarbrough, S. C. 1986: Oil and gas developments in Europe 1985. Bull. Am. Ass. Petrol. Geol. 70, 1578-1610. 
Plate 1. Kerogen

A. Sample with a relatively low $(0.21 \%$ TOC) kerogen content and a dominance of finely disseminated amorphous kerogen in a silica gel, Lafayette Bugt Formation, Nyeboe Land, GGU 316490-1, unsieved organic material.

B. As A., Lafayette Bugt Formation, Nyeboe Land, GGU $316490-2$, sieved organic material (on $10 \mu \mathrm{m}$ nylon mesh).

C. Sample with a relatively moderate $(1.15 \%$ TOC) kerogen content and small to moderate amounts of large amorphous kerogen particles, Thors Fjord Member, Nares Land, GGU 318007-18-1 unsieved organic material.

\section{Plate 2. Cambrian palynomorphs}

A. Acritarch-like folded alga. Middle Cambrian Sydpasset Formation, Freuchen Land, MGUH 19334 from GGU 315873-2; 139.5-13.9.

B. Acritarch-like folded alga. Middle Cambrian Sydpasset Formation, Freuchen Land, MGUH 19335 from GGU 315873-2; 150.6-7.0.

C. Two acritarch-like folded algae. Middle Cambrian Sydpasset Formation, Freuchen Land, MGUH 19336 (large light body), MGUH 19337 (dark small body), both from GGU 315873-2; 122.0-15.3.

D. Acritarch-like folded alga. Middle Cambrian, Ekspedition Bræ Formation, Freuchen Land, MGUH 19338 from GGU 324217-2; 139.2-14.9.

E. Acritarch-like folded alga. Middle Cambrian, Ekspedition Bræ Formation, Freuchen Land, MGUH 19339 from GGU $324300-2 ; 131.2-13.4$.

\section{Plate 3. Ordovician palynomorphs}

A. Acritarch. Upper Ordovician Troedsson Cliff Member, Washington Land, MGUH 19344 from GGU 316968-2; 145.3-17.8.

B. Acritarch. Upper Ordovician - Lower Silurian Aleqatsiaq Fjord Formation, Washington Land, MGUH 19345 from GGU $316085-4 ; 124.1-21.3$.

C. Graptolite fragment, Upper Ordovician Troedsson Cliff Member, Washington Land, MGUH 19346 from GGU 316968-2; 128.1-2.9.

D. Scolecodont, Upper Ordovician, Troedsson Cliff Member, Washington Land, MGUH 19347 from GGU 316968-2; 148.8-15.1.

E. Alga. Upper Ordovician - Lower Silurian Aleqatsiaq Formation, Nyeboe Land, MGUH 19348 from GGU 316103-2; 135.0-15.0.

F. Filamentous alga. Upper Ordovician - Lower Silurian Aleqatsiaq Formation, Washington Land, MGUH 19349 from GGU $316058-2 ; 135.1-4.2$.

\section{Plate 4. Silurian palynomorphs}

A. Chitinozoan, Angochitina cf. A. elongata. Upper Silurian Wulff Land Formation, Wulff Land, MGUH 19350 from GGU 315950-3; 136.9-17.2.

B. Chitinozoans, Linochitina erratica. Upper Silurian Wulff Land Formation, Wulff Land, MGUH 19351 from GGU 315950-2; 154.3-9.6.

C. Retiolites, graptolite fragment. Upper Silurian, Wulff Land Formation, Wulff Land, MGUH 19352 from GGU 315950-3; 155.1-11.1.

D. Graptolite fragment, Upper Silurian, Wulff Land Formation, Wulff Land, MGUH 19353 from GGU 315950-2; 127.3-5.7.

E.-H. Trilete spore-like bodies, figs $\mathrm{E}$ and $\mathrm{F}$ with a degraded bitumen-like appearance.

E. Lower Silurian Lafayette Bugt Formation, Washington Land, MGUH 19354 from GGU 211760-2; 143.3-17.2. F. Upper Silurian Wulff Land Formation, Wulff Land, MGUH 19355 from GGU 315950-3; 15950-3; 155.5-8.2.
D. As C., Thors Fjord Member, Nares Land, GGU $318007-$ $18-2$, sieved organic material (on $10 \mu \mathrm{m}$ nylon mesh).

E. Sample with a relatively large $(5.09 \%$ TOC) kerogen content and a dominance of large amorphous kerogen particles, Thors Fjord Member, Nares Land, GGU 318007-32-1, unsieved organic material.

F. As E., Thors Fjord Member, Nares Land, GGU $318007-$ $32-2$, sieved organic material (on $10 \mu \mathrm{m}$ nylon mesh).

Scale bar: $20 \mu \mathrm{m}$

F. Acritarch-like folded alga. Middle Cambrian, Ekspedition Bræ Formation, Freuchen Land, MGUH 19340 from GGU 324217-2; 141.9-11.4.

G. Lump of algal or spore-like elements. Middle Cambrian, Ekspedition Bræ Formation, Freuchen Land, MGUH 19341 from GGU 324300-2; 127.8-14.4.

H. Diad-like lump of algal or spore-like elements. Middle Cambrian, Ekspedition Bræ Formation, Freuchen Land, MGUH 19342 from GGU 314300-2; 138.5-17.8.

I. Lump of alga or spore-like elements. Middle Cambrian, Ekspedition Bræ Formation, Freuchen Land, MGUH 19343 from GGU 324300-2; 157.7-14.7.

Scale bar: $20 \mu \mathrm{m}$

G.-L. Spores with trilete rays. Upper Ordovician, Troedsson Cliff Member, Washington Land (Nøhr-Hansen \& Koppelhus, 1988).

G.-I. Besselia nunaatica, MGUH 17539 from GGU 316968-2; 125.5-8.3.

G. Distal view illustrating the minute ornamentation.

H. Equatorial view.

I. Internal proximal view.

J. Besselia nunaatica, two connected spores, internal proximal view, MGUH 17541 from GGU 316968-2; 155.1-11.9. K.-L. Besselia nunaatica. MGUH 17542 from GGU 316968-2; 123.8-15.9.

$\mathrm{K}$. Distal view illustrating the ornamentation.

L. Internal proximal view.

Scale bar: $20 \mu \mathrm{m}$

G. Upper Silurian Nyeboe Land Formation, Nyeboe Land, MGUH 19356 from GGU 319234-2; 119.3-11.0.

H. Upper Silurian Nyeboe Land Formation, Wulff Land, MGUH 19357 from GGU 319210-3; 130.6-21.4.

I. Spherical folded algae, acritarchs? Lower Silurian Lafayette Bugt Formation, Hall Land, MGUH 19358 from GGU 324157-2; 144.2-8.5.

J. Tubular structure. Upper Silurian Nyeboe Land Formation, Wulff Land, MGUH 19359 from GGU 319210-3; 146.6-16.5.

K. Tubular structure. Upper Silurian Nyeboe Land Formation, Nyeboe Land, MGUH 19360 from GGU 319234-2; 138.8-8.0.

L. Rounded drop-shaped palynomorphs. Lower Silurian Lafayette Bugt Formation, Washington Land, MGUH 19361 from GGU 316061-2; 137.1-14.8.

Scale bar: $20 \mu \mathrm{m}$. 
Plate 1. Kerogen

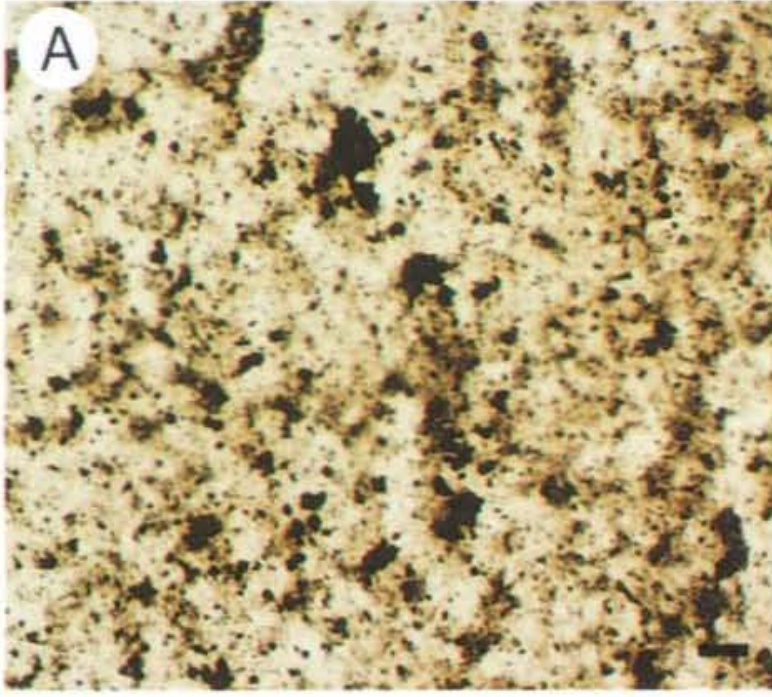

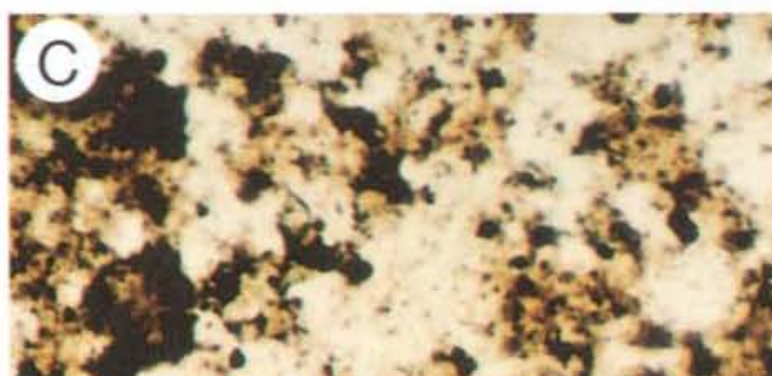

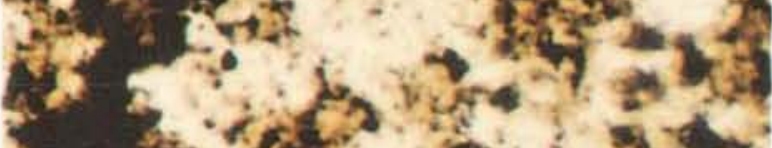

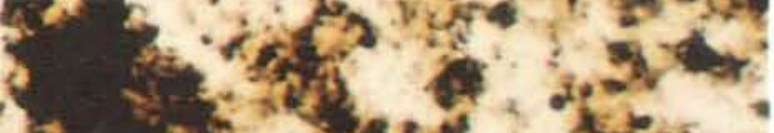

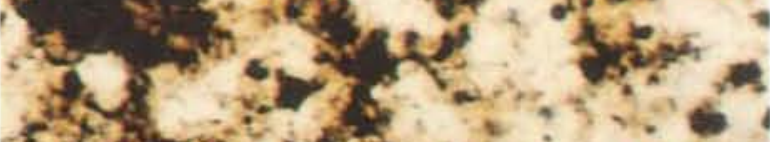
क्री

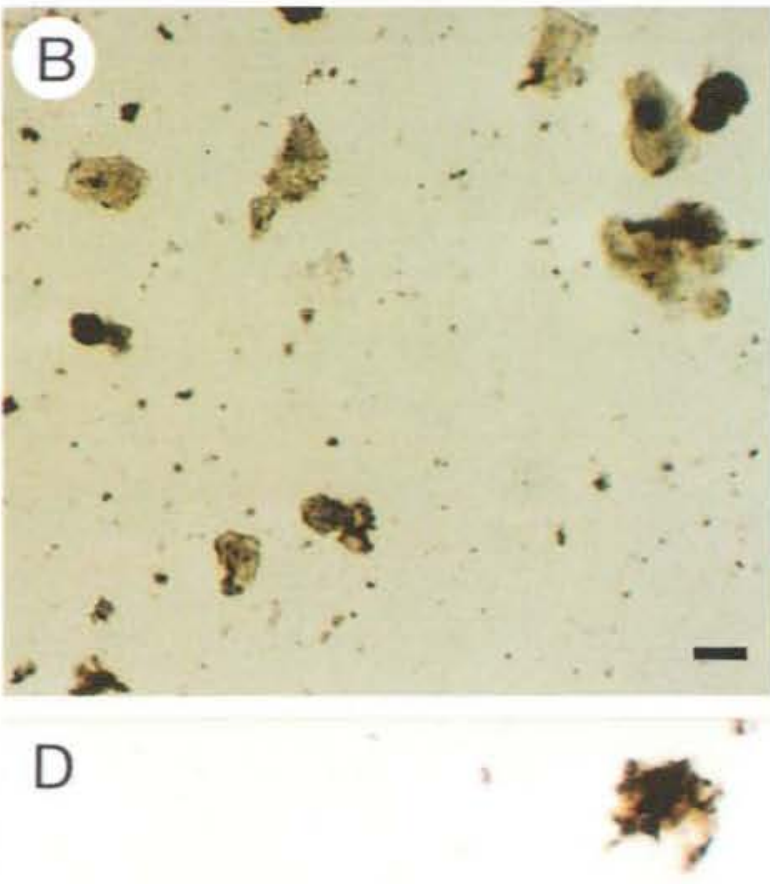

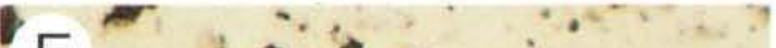
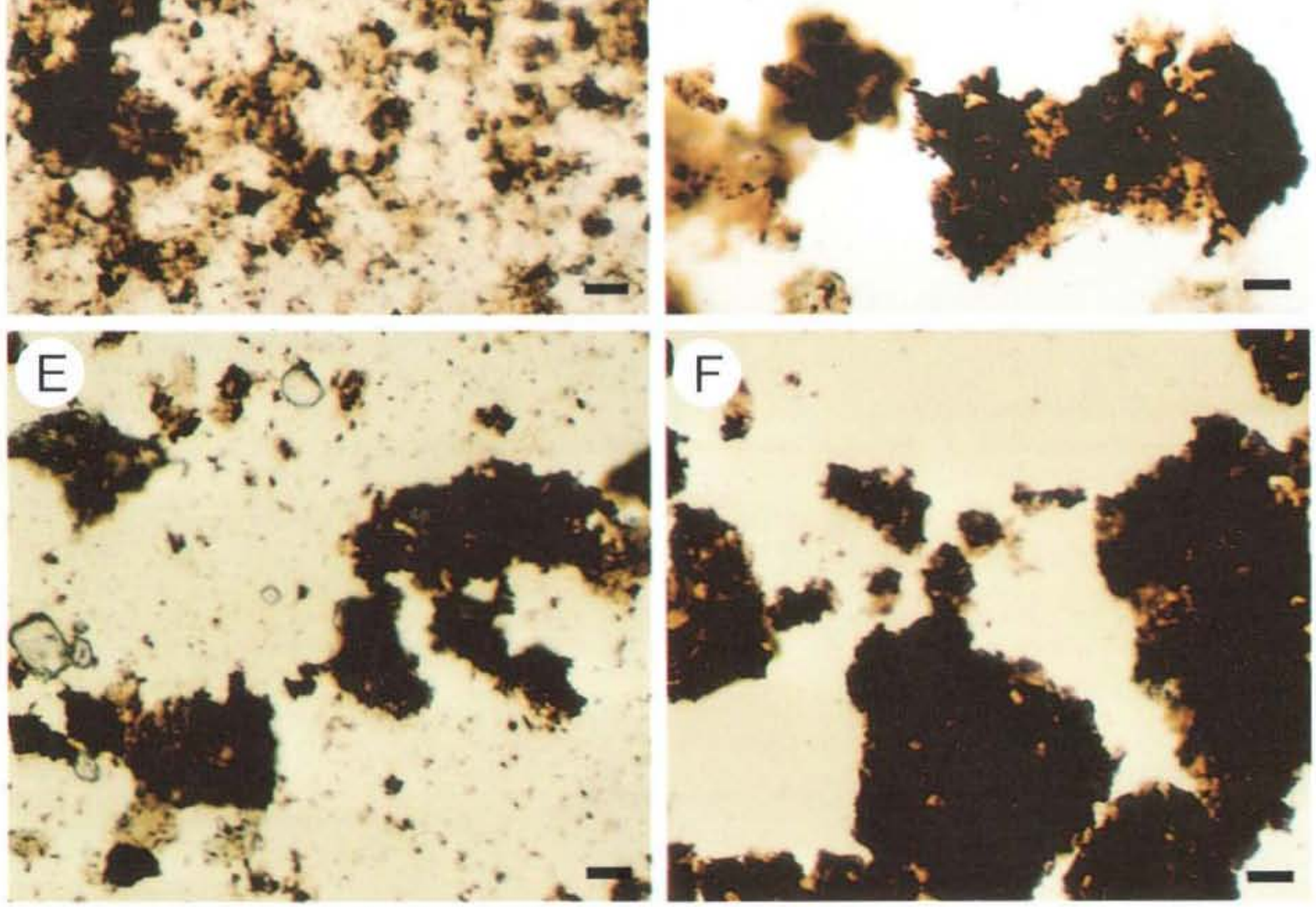
Plate 2. Cambrian palynomorphs

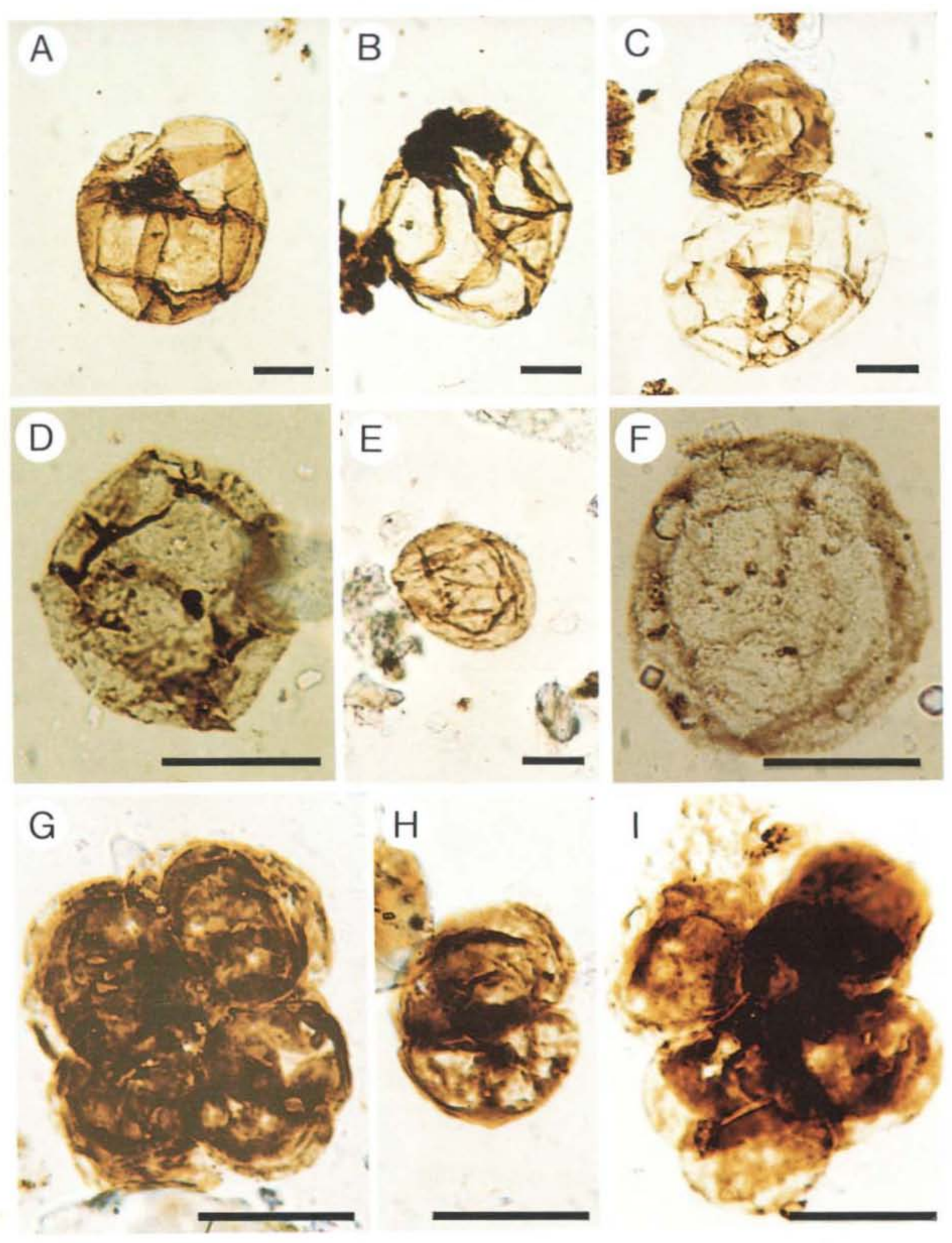


Plate 3. Ordovician palynomorphs
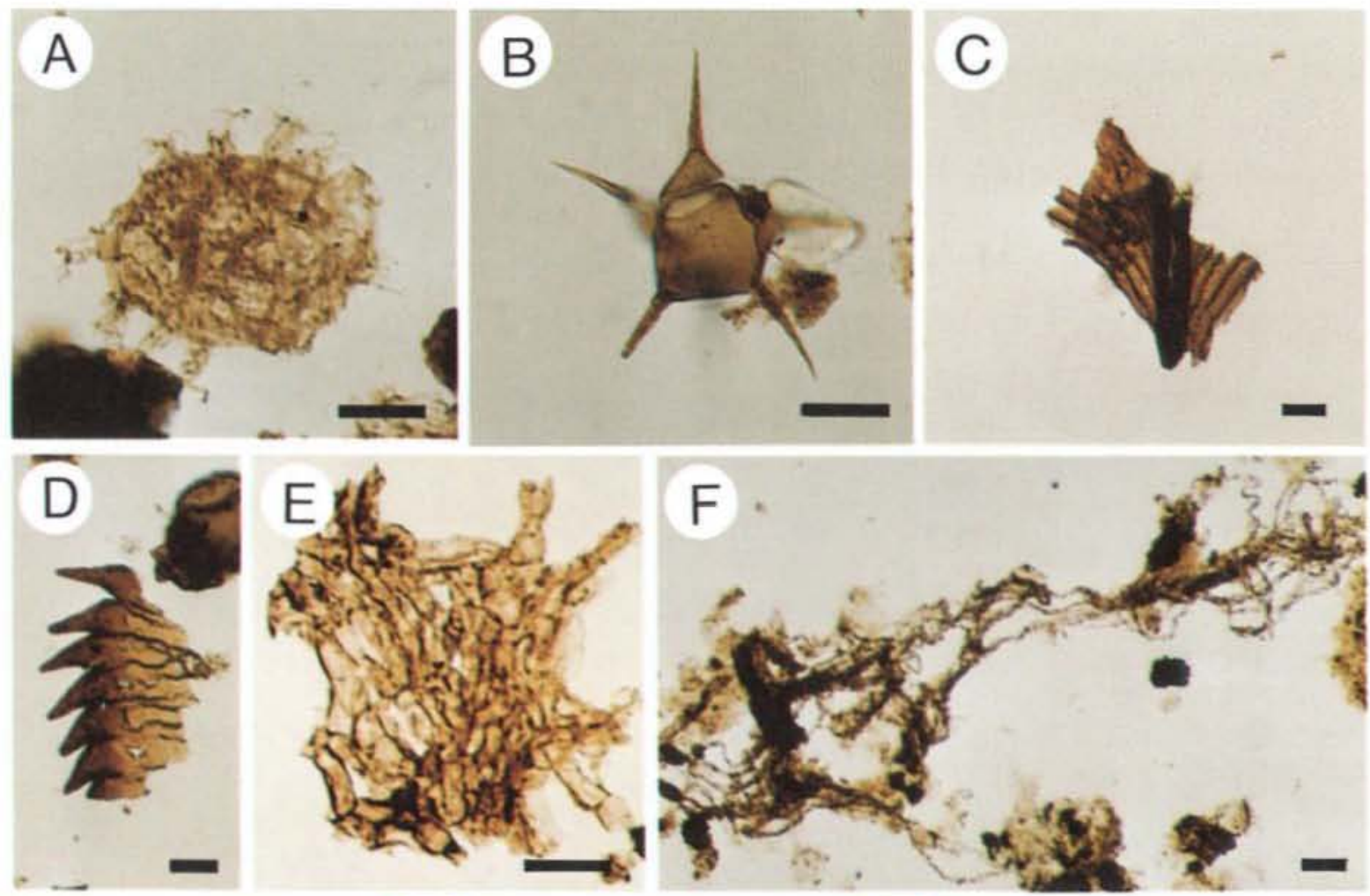

G
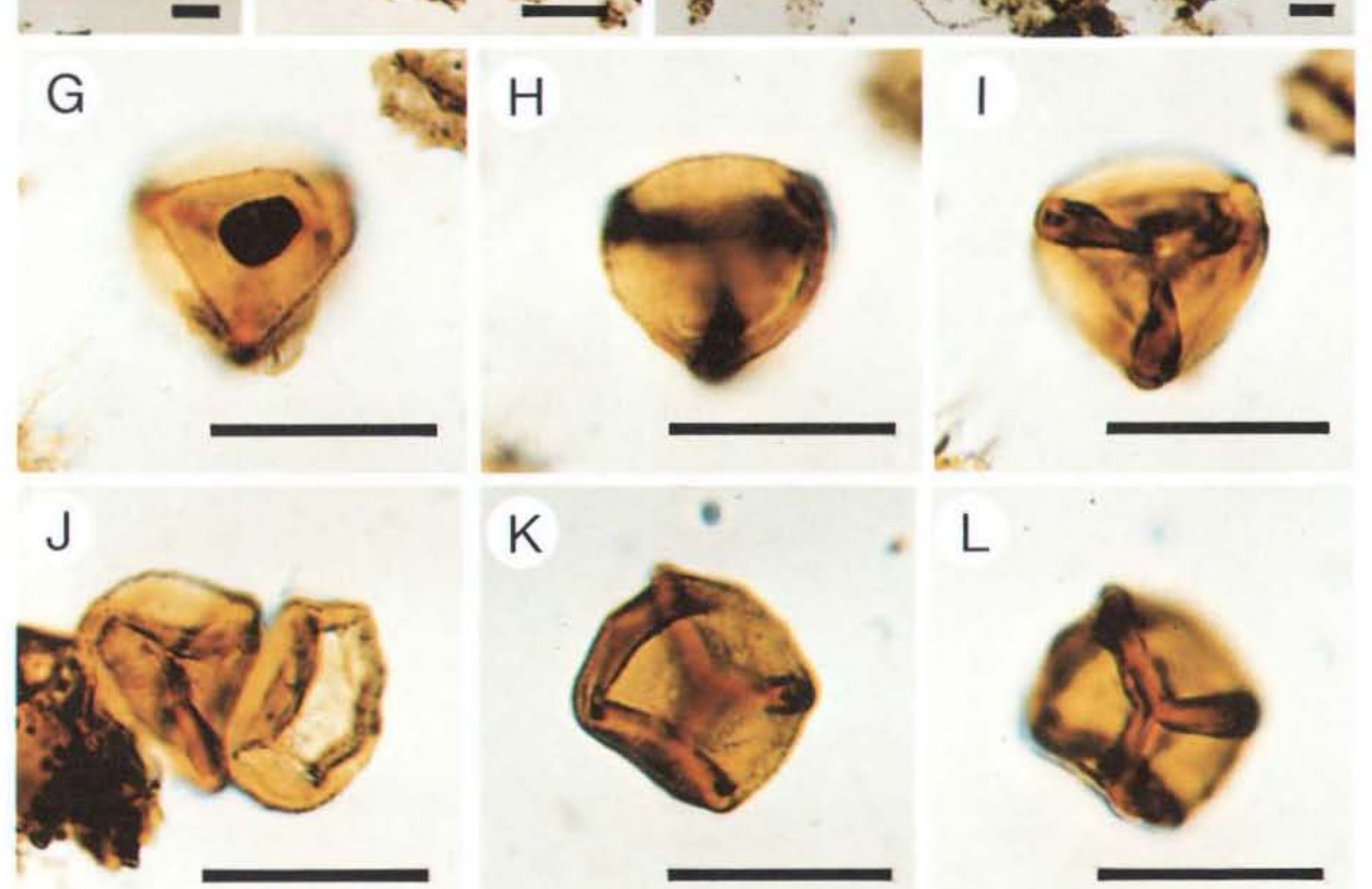
Plate 4. Silurian palynomorphs

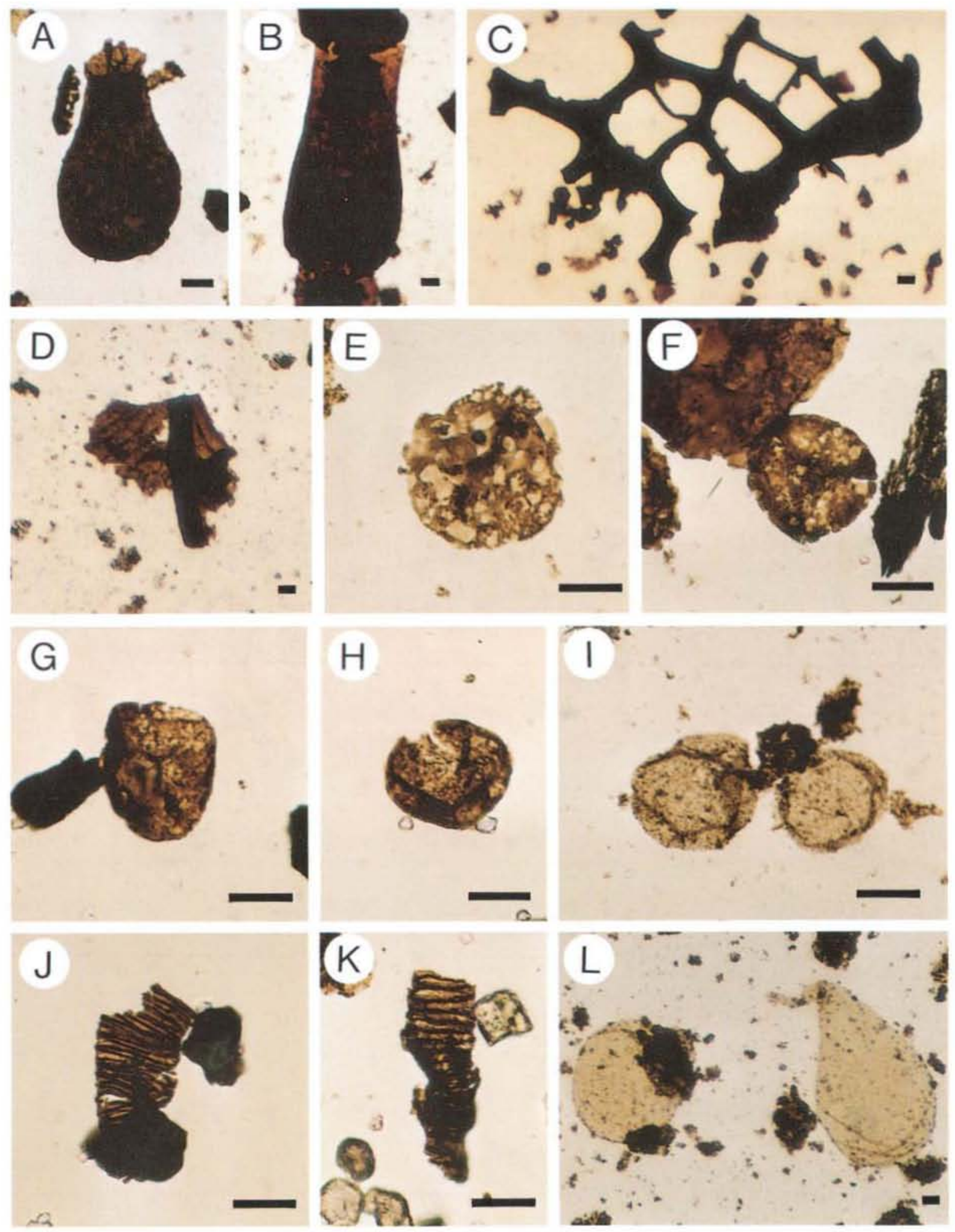


Plate 5. Progressive coloration of amorphous kerogen with increasing thermal alteration
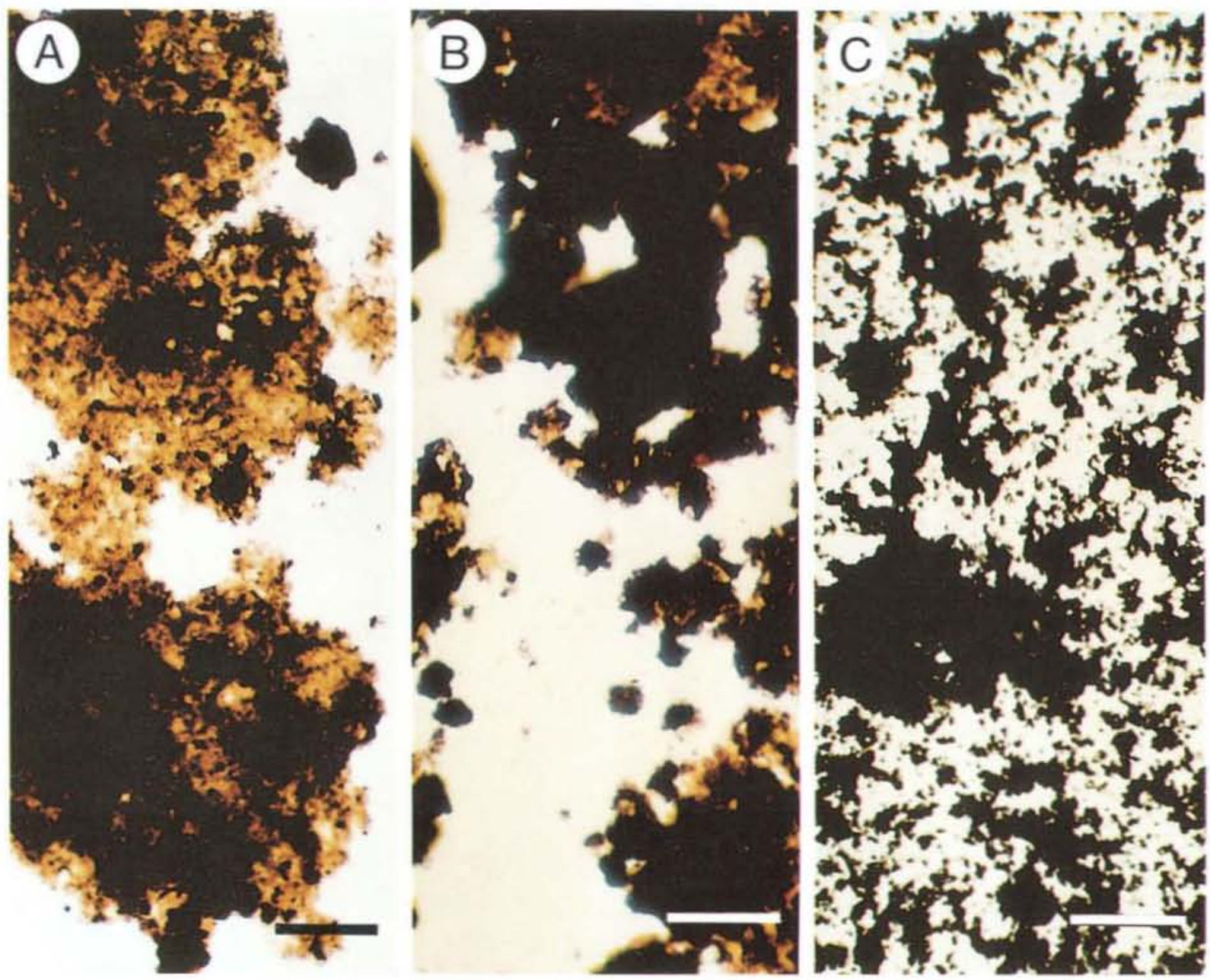

Plate 5. Progressive coloration of amorphous kerogen with increasing thermal alteration Scale bar: $50 \mu \mathrm{m}$
A. TAI: (2)-2+, GGU $211759-2$.
B. TAI: $2^{+}-\left(3^{-}\right)$, GGU $324405-2$.
C. TAI: $4^{+}$, GGU $316475-1$. 
Plate 6. Change in structure of amorphous kerogen with increasing thermal alteration as observed in the scanning electron microscope
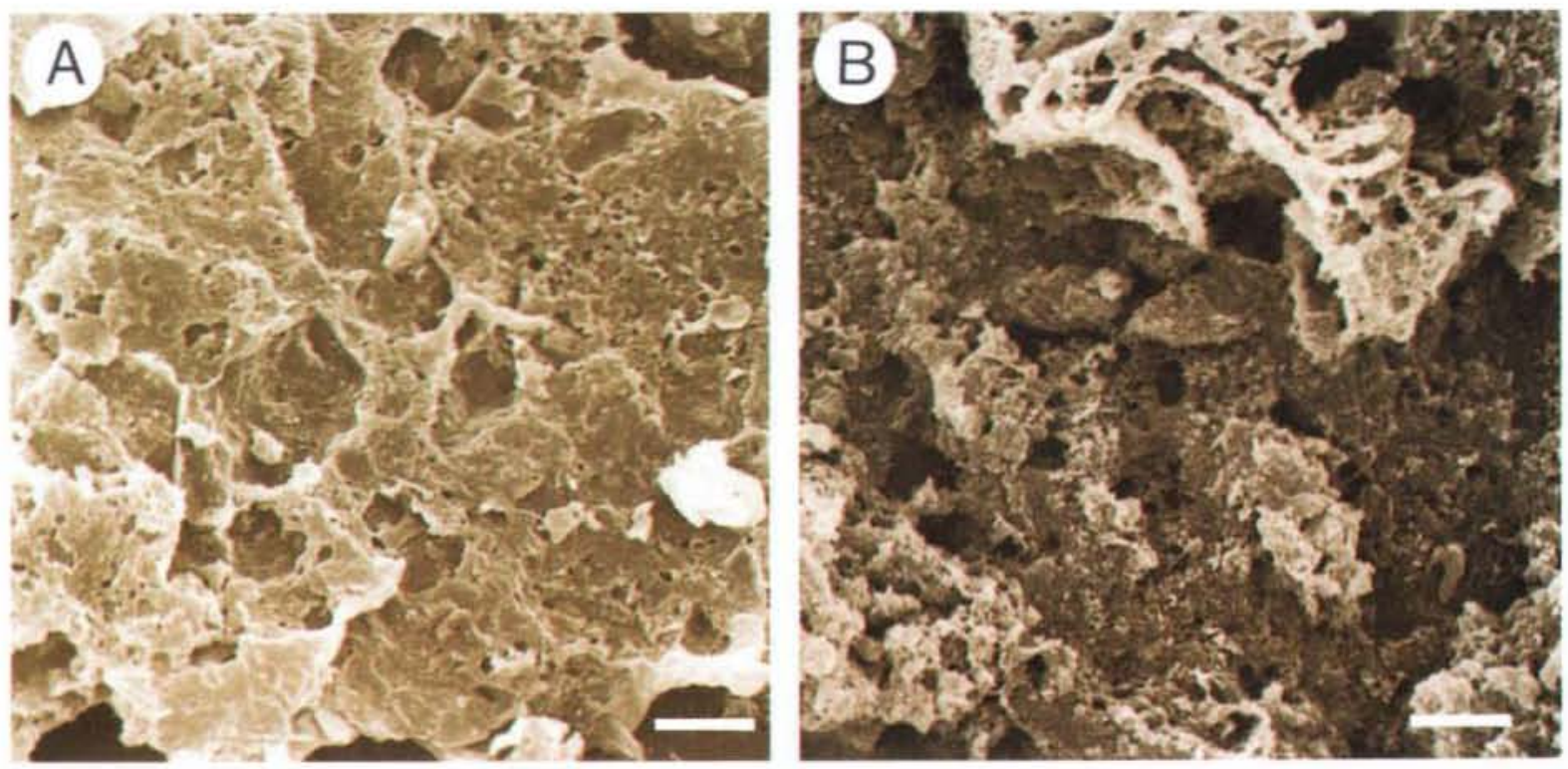

Plate 6. Change in structure of amorphous kerogen with increasing thermal alteration as observed in the scanning electron microscope

A. TAI: $2^{*}-(3), T_{\max }: 446$, GGU $324405-2$, scale bar: $10 \mu \mathrm{m}$.

Plate 7. Field appearance of bitumen

A. Seeping asphalt from southern Wulff Land (equivalent to GGU 324200).

Plate 8. Macroscopic bitumen in slabs

A. Asphalt from seep in dolomite breccia. GGU $324200 \mathrm{~A}$.

B. Like A. Stained. D0, D1, D2, C1, C2 correspond to generations of dolomite and calcite.

\section{Plate 9. Bitumen in thin section}

A. Bitumen in coral. GGU 324130B, Lafayette Bugt Formation. Nyeboe Land. Plane light, stained, C: calcite, Fe-C: Fe-rich calcite, B: bitumen, scale bar: $1 \mathrm{~mm}$.

B. Bitumen in coral. GGU 316067, Lafayette Bugt Formation, Washington Land. Crossed nicols + gypsum plate. Q: quartz, C: calcite, B: bitumen, scale bar: $1 \mathrm{~mm}$.

C. Bitumen-filled fracture in calcarenite. GGU 318013-09, Lafayette Bugt Formation. Nyeboe Land. Plane light, scale bar: $2 \mathrm{~mm}$.
B. TAI: $4^{*}, T_{\max }: \mathrm{n} . \mathrm{d}$, GGU $316475-2$, scale bar: $10 \mu \mathrm{m}$.

B. Hard solid bitumen in dolomite vug in the Sydpasset Formation (equivalent to GGU 324287-324299, core GGU 318003).

C. Asphalt from seep in dolomite breccia. Stained. Same generations of carbonates as A and B. GGU $324200 \mathrm{E}$.

D. Hard solid bitumen in vugs and veins in dolomite grainstone. DO: dolomite grainstone, D1: saddle dolomite. Core GGU 318003 .

D. Two-phased bitumen (black and yellow) (B1, B2) in saddle dolomite veins (D1) cross-cutting dolomite grainstone (D0). See close-up (arrow) in Plate 11. GGU 318003-53, Henson Gletscher Formation, Freuchen Land. Plane light, scale bar: $2 \mathrm{~mm}$.

E.-F. Saddle dolomite vein (D1) in dolomite grainstone (D0). Bitumen occurs as impregnation in DO (B1), as residual matter in the contact between D0 and D1 (B2, $R_{0}: 0.92 \%$ ) and in the centre of the vein (B3, $R_{v}: 1.21 \%$ ). GGU 318003-21. Sydpasset Formation, Freuchen Land. Plane light, scale bars: $1 \mathrm{~mm}$.

Plate 10. Bitumen in palynologically prepared samples observed in microscope or in SEM

A. Bitumen with flaky appearance (note crystal impressions). GGU 315172-1. Ryder Gletscher Group Fm 6, Wulff Land. Scale bar: $25 \mathrm{um}$.

B. Globular bitumen. GGU 315865-2, Aftenstjernesø Formation, Nares Land, scale bar: $50 \mu \mathrm{m}$.

C. Globular bitumen which has been extruded during and after sample preparation by the xylene-containing mounting medium. GGU 315199, Ryder Gletscher Group Fm 6. Warming Land. Scale bar: $12.5 \mu \mathrm{m}$.
D. Bitumen with flaky appearance (note crystal impressions). GGU 315172-1. Ryder Gletscher Group Fm 6, Wulff Land. Scale bar: $10 \mu \mathrm{m}$.

E. Bitumen mirroring imprints of crystals from coral space. GGU 316067-2. Lafayette Bugt Formation, Washington Land. Scale bar: $10 \mu \mathrm{m}$.

F. Thread-like bitumen. GGU 324453, Buen Formation, Wulff Land. Scale bar: $25 \mu \mathrm{m}$. 
Plate 7. Field appearance of bitumen

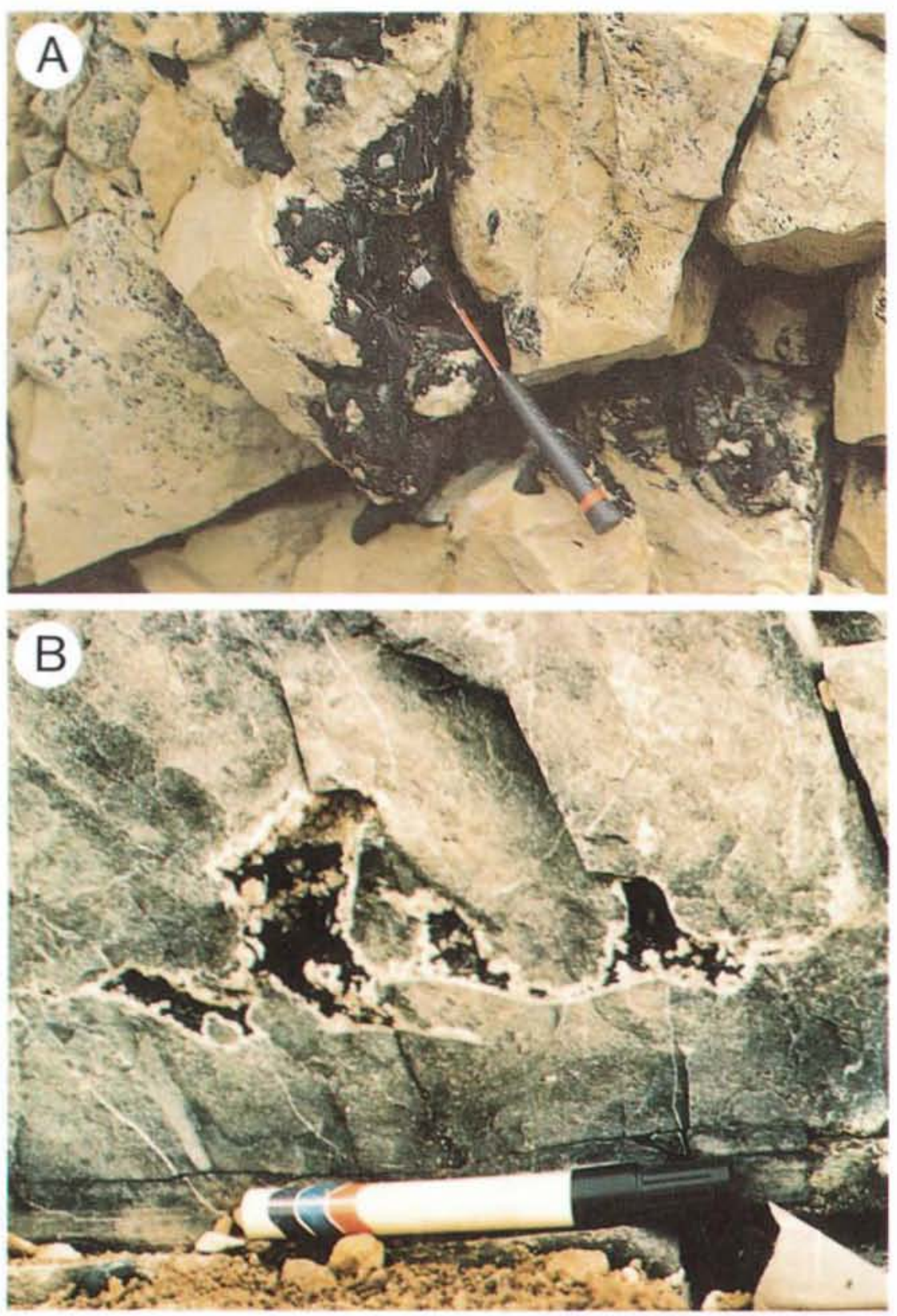


Plate 8. Macroscopic bitumen in slabs
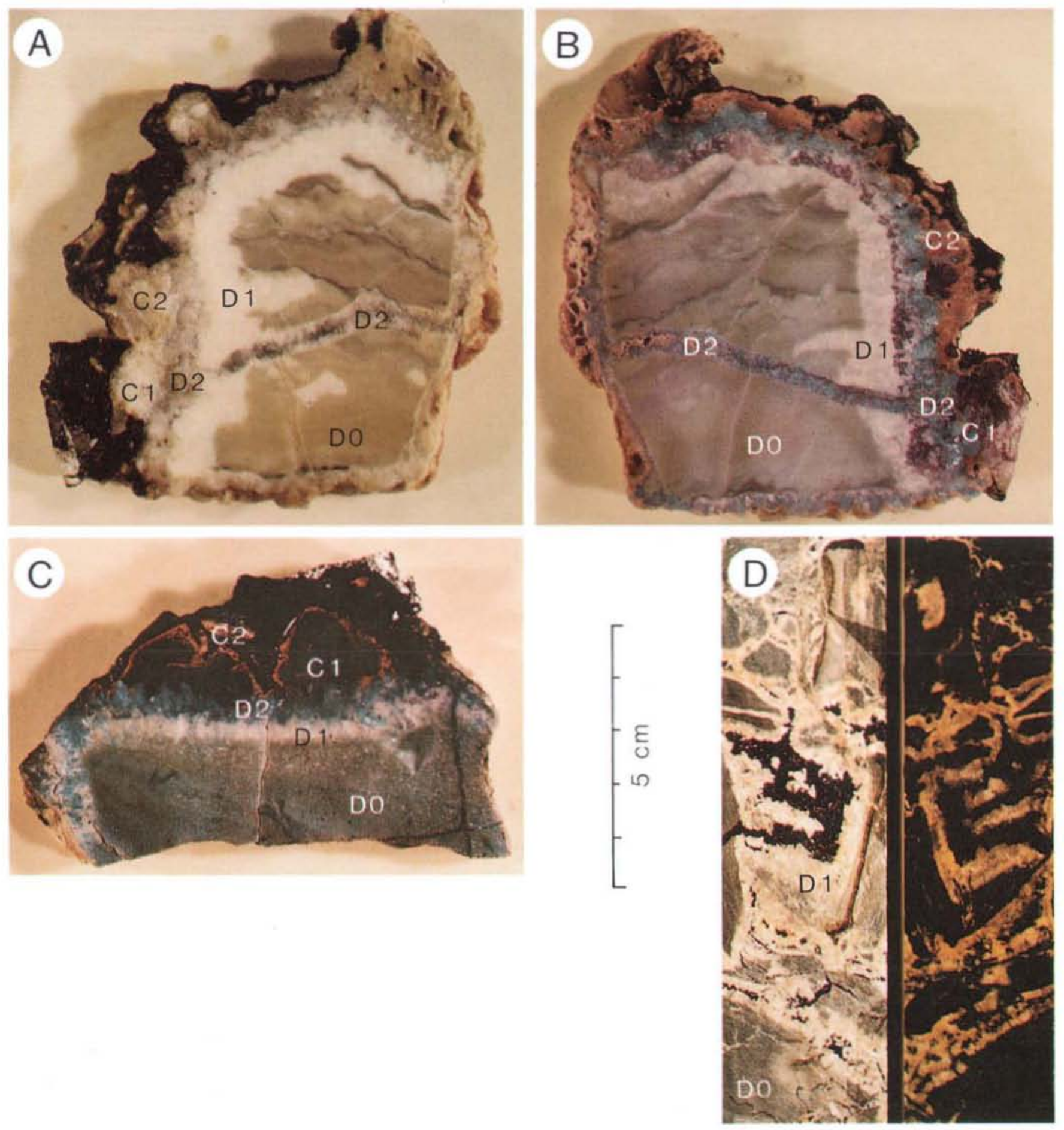
Plate 9. Bitumen in thin section

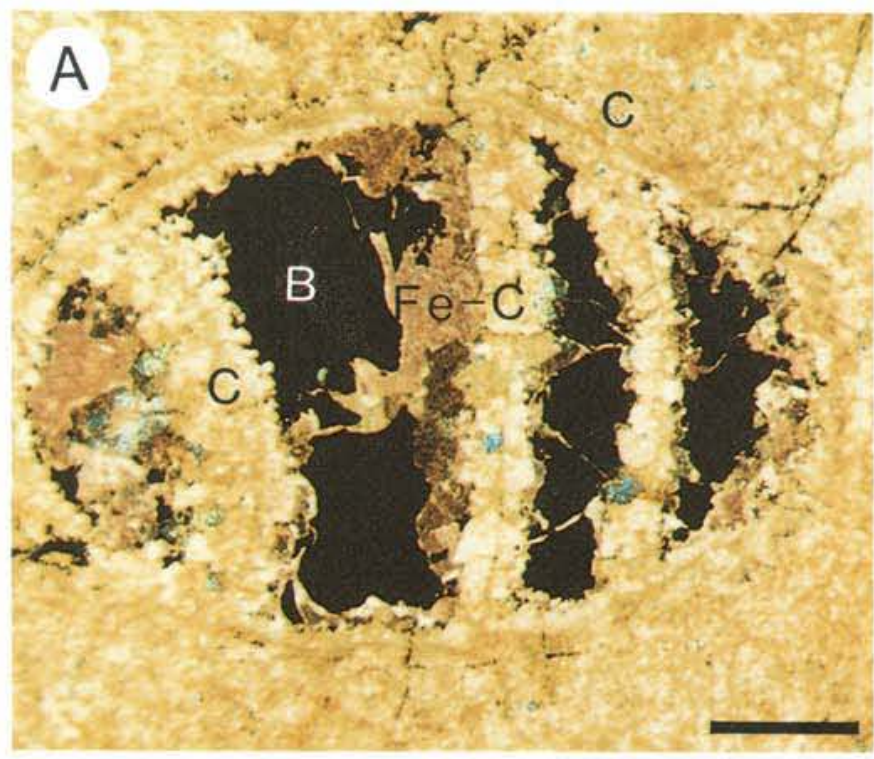

C

F. Af:
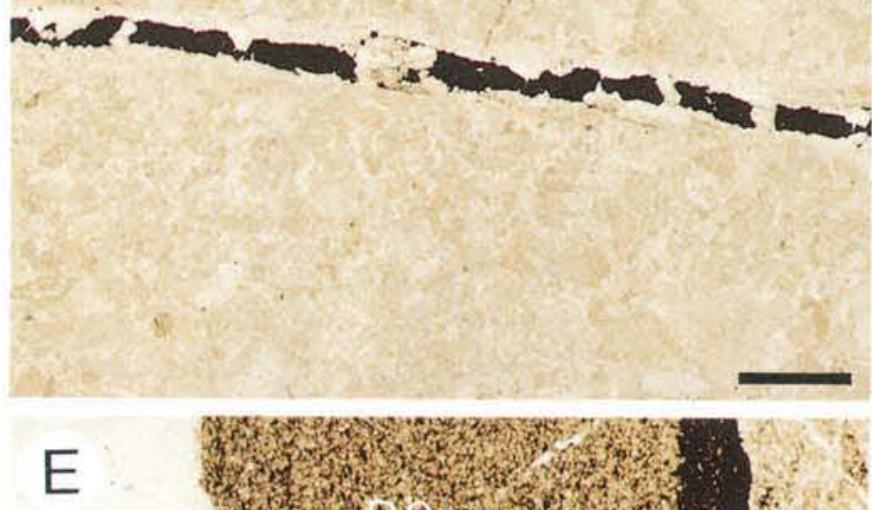

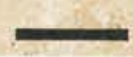

E

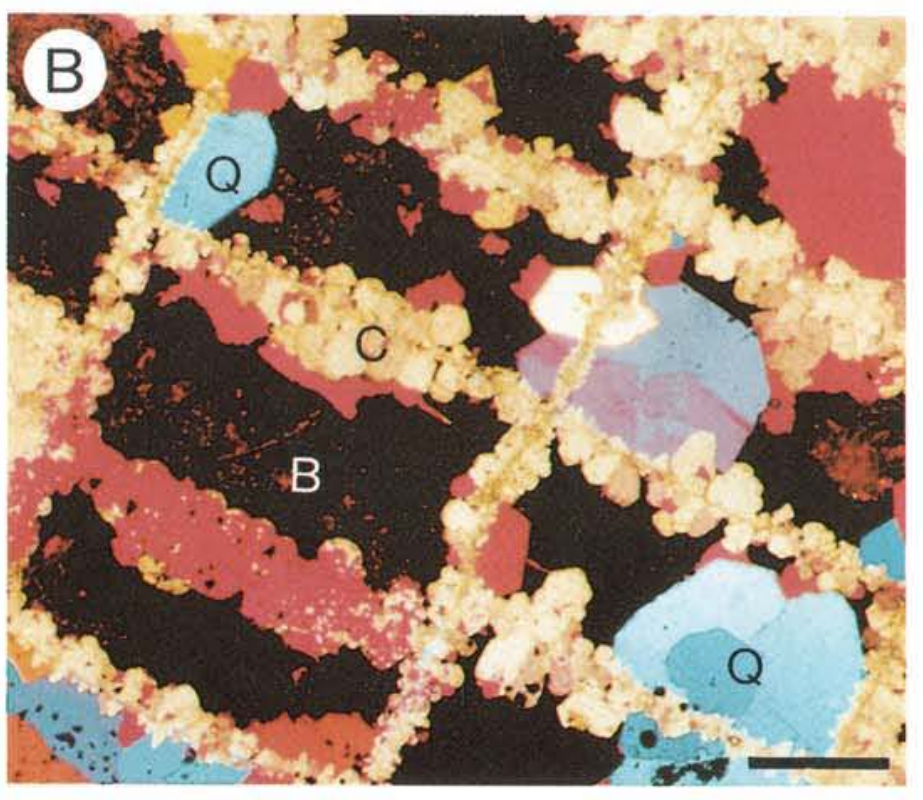

D

Dó

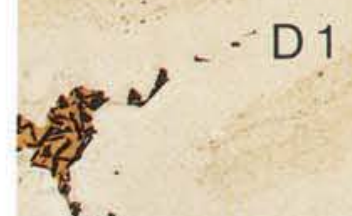

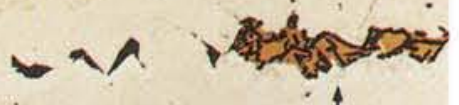 \\ $\mathrm{B} 1,{ }^{4} \mathrm{~B} 2$}

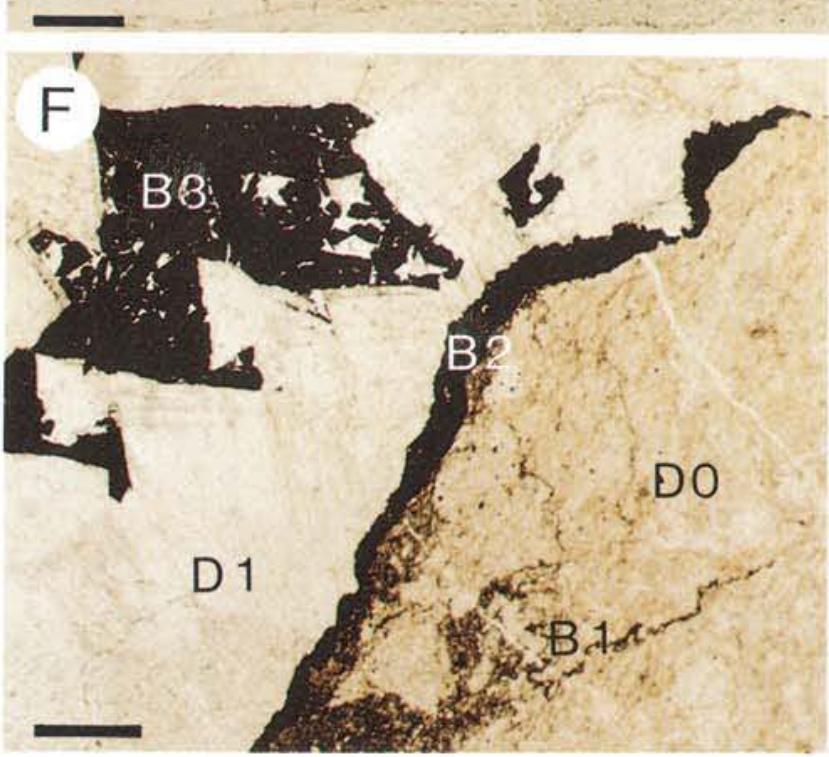


Plate 10. Bitumen in palynologically prepared samples observed in microscope or in SEM
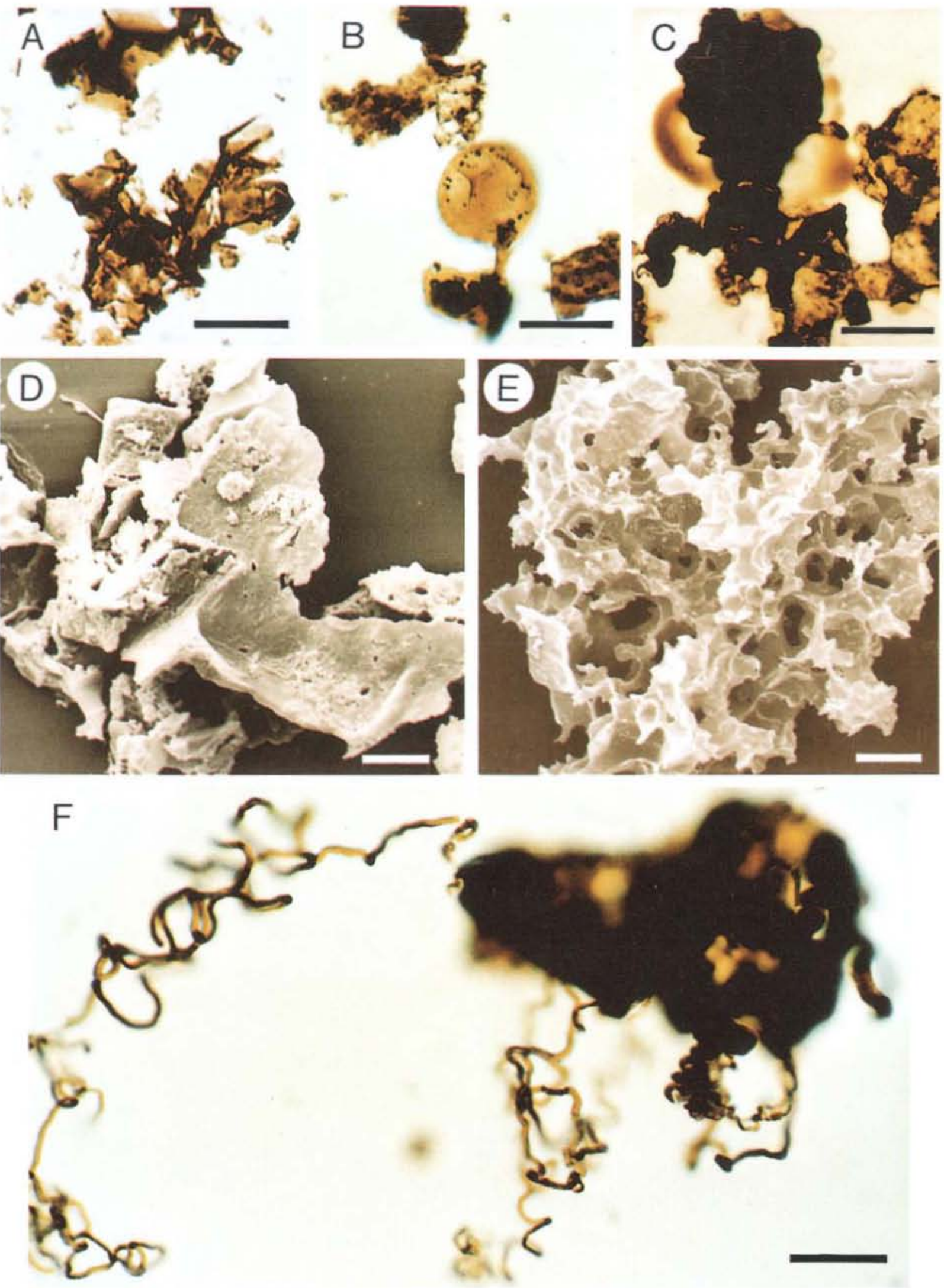
Plate 11. Bitumen in polished section
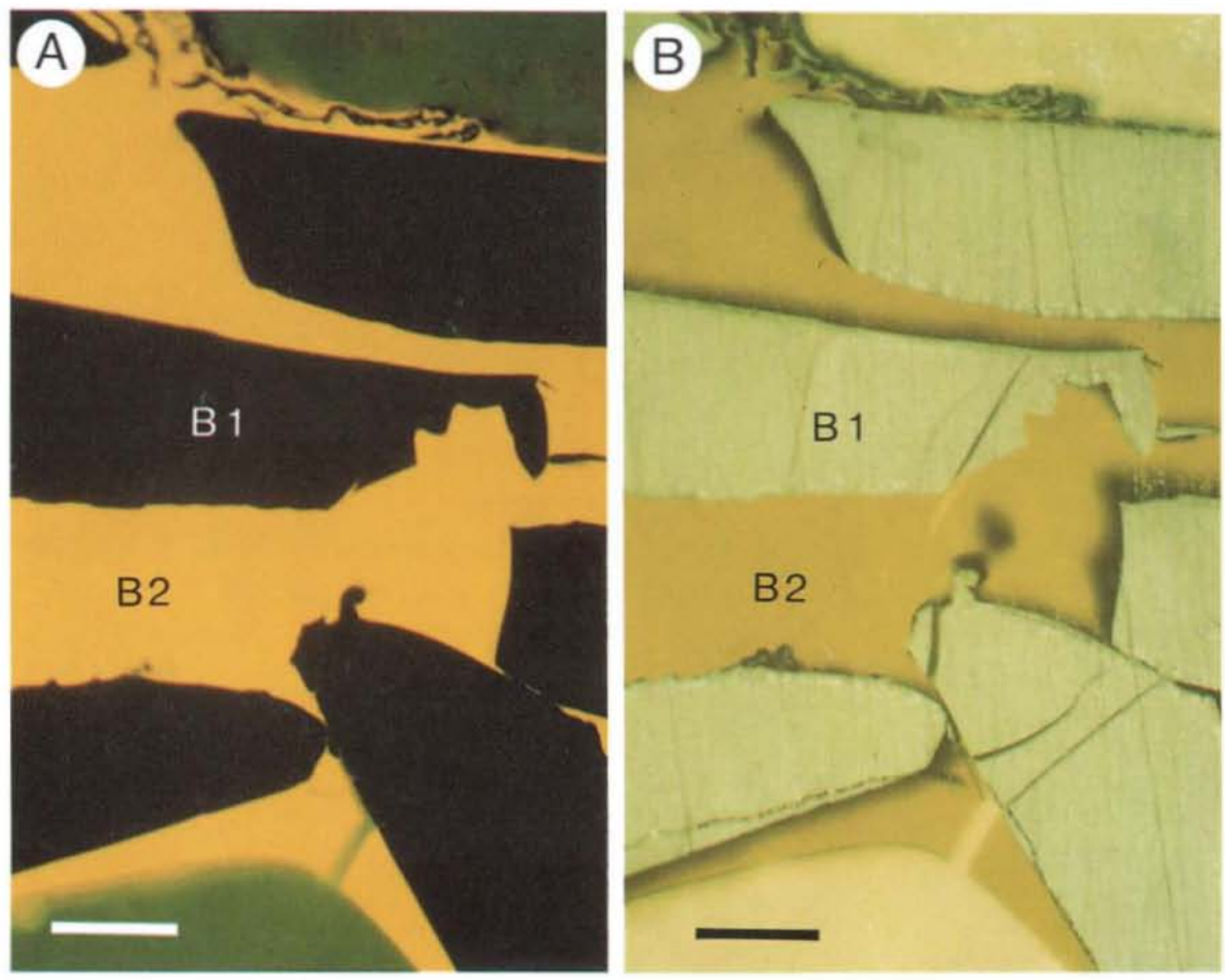

Plate 11. Bitumen in polished section

GGU 318003-53, Henson Gletscher Formation, Freuchen Land.

Scale bar: $50 \mu \mathrm{m}$

A. Fluorescent light photograph of two-phase bitumen.

B. Normal reflected light photograph of same field. The yellow-fluorescent low-reflecting bitumen (B2) has a $\mathbf{R}_{\mathrm{o}}$ of $0.08 \%$ and the dark non-fluorescent high-reflecting bitumen (B1) a $\mathrm{R}_{\mathrm{o}}$ of $1.17 \%$.

\section{Cover picture}

Cambrian and Ordovician strata at Blue Cliffs, Wulff Land, North Greenland. Photo: J. Lautrup, GGU. 